\title{
Stratigraphy and Coal Resources of the Makarwal Area, Trans-Indus Mountains, Mianwali District, Pakistan
}

U.S. GEOLOGICAL \$URVEY PROFESSIONAL PAPER 1341

Prepared in cooperation with the Geological Survey of Pakistan, under the auspices of the U:S. Department of State and the Government of Pakistan

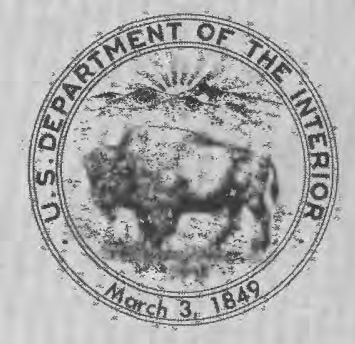




\title{
Stratigraphy and Coal Resources of the Makarwal Area, Trans-Indus Mountains, Mianwali District, Pakistan
}

\author{
By WALTER DANILCHIK and S. M. IBRAHIM SHAH
}

U.S. GEOLOGICAL SURVEY PROFESSIONAL PAPER 1341

Prepared in cooperation with the Geological Survey of Pakistan, under the auspices of the U.S. Department of State and the Government of Pakistan

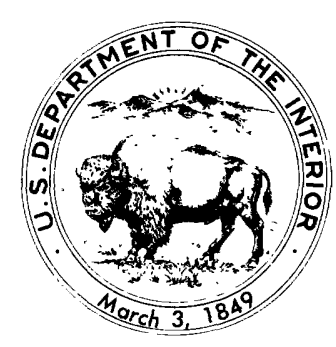




\section{DEPARTMENT OF THE INTERIOR \\ DONALD PAUL HODEL, Secretary}

\section{U.S. GEOLOGICAL SLRVEY}

Dallas L. Peck, Director

\section{Library of Congress Cataloging in Publication Data}

Danilchik, Walter.

Stratigraphy and coal resources of the Makarwal Area, Trans-Indus Mountains, Mianwali District, Pakistan.

(Geological Survey professional paper ; 1341)

"Prepared in cooperation with the Geological Survey of Pakistan, under the auspices of the U.S. Department of State and the Government of Pakistan."

Bibliography: p. 37

Supt. of Docs. no.: I 19.16:1341

1. Geology-Pakistan-Mianwali District. 2. Coal-Geology-Pakistan-Mianwali District. I. Shah, S. M. Ibrahim. II. Geological Survey of Pakistan. III. Title. IV. Series.

QE295.4D36 $1985 \quad 553.2^{\prime} 4^{\prime} 09549144 \quad 84-600255$

For sale by the Books and Open-File Reports Section, U.S. Geological Survey, Federal Center, Box 25425, Denver, CO 80225 


\section{FOREWORD}

In 1956, the Geological Survey of Pakistan and the U.S. Geological Survey began a cooperative program to intensify the mapping and appraisal of Pakistan's geological resources. The program was initiated under an agreement dated October 1955 between the Government of Pakistan and the International Cooperation Administration, predecessor of the Agency for International Development, U.S. Department of State. It included joint geological reconnaissance of unmapped areas, detailed mapping and appraisal of mineral districts, and development of facilities and staff to increase the capacity of the Geological Survey of Pakistan.

Detailed information from these investigations, as well as reports from other studies made during the program, are available from the Geological Survey of Pakistan in Quetta. Much of the regional geological information obtained during this program, and from surveys made earlier, was summarized in a new Geological Map of Pakistan prepared cooperatively and published by the Geological Survey of Pakistan in 1964.

The cooperative program in Pakistan, which directly involved the services of about 110 professional personnel from Pakistan and 43 from the United States, operated successively under the direction of four Directors-General of the Geological Survey of Pakistan and three Chiefs of Party appointed by the U.S. Geological Survey. Program directors for Pakistan were E. R. Gee (1956-59), N. M. Khan (1959-64), A. F. M. M. Haque (1964-69), and A. M. Khan (1969-70). United States participation was supervised by J. A. Reinemund (1956-63), M. G. White (1963-66), and D. L. Rossman (1967-70), each of whom also served as senior geologic consultant to the Director-General.

Geologic specialists provided by the U.S. Geological Survey were supplemented by four mining engineers from the U.S. Bureau of Mines, who provided collateral assistance to the Pakistan Department of Mineral Development, and by a drilling specialist and an administrative specialist from the Agency for International Development. The Geological Survey of Pakistan, through the Ministry of Industries and Natural Resources, provided counterpart personnel, facilities, and services for the program, and arranged cooperative support from the Pakistan Department of Mineral Development, as well as from the Pakistan Industrial Development Corporation, Pakistan Council of Scientific and Industrial Research, and other agencies concerned with resource development.

This program would not have been possible without the excellent support of all agencies involved, both in Pakistan and the United States. The geological information and institutional growth obtained through this program should contribute significantly toward orderly economic and scientific development in one of Asia's largest and newest nations.

Abdul Mannan Khan, Director-General Geological Survey of Pakistan

John A. Reinemund, Chief Office of International Geology U.S. Geological Survey 



\section{CONTENTS}

Foreword

Abstract

Introduction

Purpose and scope of report

Transport and accessibility

Climate

Previous geologic work --_-_-_-_-_-_-_-_-_-_-_-

Present investigations

Acknowledgments

Stratigraphy

Permian System, Upper Permian Series -_-_-_-_-_-_-_Zaluch Group

Triassic and Triassic(?) Systems

Mianwali Formation

Tredian Formation

Kingriali Dolomits

Jurassic System --_.

Datta Formation -_.

Shinawari Formation

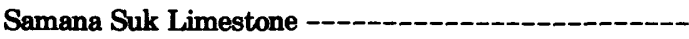

Cretaceous and Cretaceous(?) System -.-_-_-_-_-_-_--.-

Chichali Formation

Lumshiwal Formation -_-

Tertiary System --

Hangu Formation

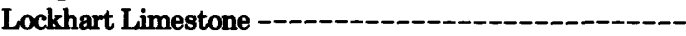

Patala Shale --_-_-_-_-_-_-_-_-_-_-_-_-_-_-_-

Nammal Marl -_-_-_-_-_-_-_-_-_-_-_-

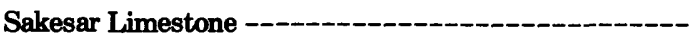

Mitha Khatak Formation
Classification of formations -

\begin{tabular}{|c|c|}
\hline Page & \\
\hline III & Stratigraphy-Continued \\
\hline 1 & Tertiary and Quaternary Systems - \\
\hline 1 & Sub-Himalayan Supergroup (in part) - \\
\hline 1 & Siwalik Group -- \\
\hline 3 & Chinji Formation -- \\
\hline 3 & Nagri Formation - \\
\hline 4 & Dhok Pathan Formation -- \\
\hline 4 & Deposits of Quaternary age -- \\
\hline 4 & Structure of the Makarwal coal field - \\
\hline 4 & Folds - \\
\hline 4 & Faults -- \\
\hline 7 & Geologic history -- \\
\hline 7 & Economic geology - \\
\hline 7 & Coal resources - - \\
\hline 7 & Thickness of the coal bed - \\
\hline 10 & Description of floor, roof, and partings of the coal bed -- \\
\hline 11 & Quality --n-_- \\
\hline 12 & Production --_- \\
\hline 12 & Reserves --_-_-_-_- \\
\hline 12 & Other mineral resources - \\
\hline 15 & Greensand - - \\
\hline 16 & Iron - \\
\hline 16 & Glass sand - - \\
\hline 17 & Limestone - \\
\hline 18 & Groundwater and engineering geology problems - \\
\hline 18 & Mine water -- \\
\hline & Water supply --_- \\
\hline 20 & 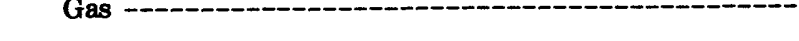 \\
\hline 20 & + \\
\hline 2. & \\
\hline
\end{tabular}

\section{ILLUSTRATIONS}

[Plates are in pocket]

Plate 1. Geologic map of the Makarwal quadrangle

2. Detailed geologic map and cross sections of the Makarwal coal field

3. Structural map, Makarwal coal field

4. Coal reserve calculation map

FIGURE 1. Index map of Pakistan showing location of coal fields and the Trans-Indus Mountain region

3. Correlation of formations in the Trans-Indus Mountains and the western Salt Range, Pakistan --_-

4. Idealized stratigraphic relationships of outcropping rocks along the Trans-Indus Mountains and western Salt Range, Pakistan -

5. Stratigraphic section of rocks exposed in the area covered by the geologic map of the Makarwal coal field ---_-

6. Cross section along the Central Tunnel -

7. Cross section along Lumshiwal Nala -

8. Coal thickness diagram -

\section{age}

23 3 3 3 4

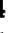
25 . 26 


\section{TABLES}

TABLE 1. Stratigraphic sequence and lithostratigraphic classification of rocks in the western Salt Range and Trans-Indus Mountains, Pakistan --

2. Summary of coal thickness measurements -

3. Chemical analyses of Makarwal coal -

4. Comparision of proximate analyses of Makarwal coal

5. Screen test on "run of mine" coal, Makarwal -

6. Coal production, Makarwal coal field, 1914 to September 1968

7. Coal reserves of the Makarwal coal field

8. Chemical analyses of greensand from the United States and from Baroch Nala in the Makarwal coal field -- - - -

9. Chemical analyses of a channel sample of the iron-rich beds, Baroch Naia, Makarwal coal field 


\title{
STRATIGRAPHY AND COAL RESOURCES OF THE MAKARWAL AREA, TRANS-INDUS MOUNTAINS, MIANWALI DISTRICT, PAKISTAN
}

\author{
By WALTER DANILCHIK and S. M. IBRAHIM SHAH ${ }^{1}$
}

\section{ABSTRACT}

Sedimentary rocks of marine and nonmarine origin ranging in age from Permian to Pleistocene constitute most of the stratigraphic sequence in the Trans-Indus Mountains in Pakistan. Their total thickness in the Surghar, Shinghar, Marwat, and Khisor Ranges exceeds 20,000 feet. The sequence consists of more than 20 formations and members that are named, in accordance with the Stratigraphic Code of Pakistan, after geographic features where they are typically developed, well exposed, and readily accessible. New names have been proposed and type sections designated for five of the formations described. Type sections and reference sections have also been designated for previously-named formations for which no type section had been formally established. Three former faunal zones in the Siwalik Group have been elevated to formation rank, and boundaries of several formations have been redefined.

The Makarwal coal field is located in Sargodha Division, Mianwali District, in the Surghar Range. The coal field serves as a source of energy and byproducts for the industrial center at Daud Khel, 34 miles by rail northeast of the coal field.

The coal-bearing strata are of Paleocene age and are overlain by younger Tertiary rocks that exceed 15,000 feet in total thickness. The coal was involved in at least two episodes of mountain-building activity that produced the Trans-Indus Mountains.

The coal is produced from a single bed that ranges in thickness from 2 feet to more than 10 feet and averages 4 feet. Most of the coal is in the west limb of the Makarwal anticline and dips $30^{\circ} \mathrm{W}$. The coal is ranked as high-volatile, C-bituminous, containing ash in the range of 7 to 22 percent; fixed carbon, 36.3 to 43.4 percent; sulfur, 4.1 to 5.6 percent; and calorific value, 9550 to $11850 \mathrm{Btu}$ (as received).

The area developed for coal mining is almost mined out. From 1914 to 1976 nearly 5 million tons of coal have been produced. The total reserves possible for development to a depth of 200 feet below sea level are $16,600,000$ tons.

Other mineral resources in the Makarwal coal field include large reserves of limestone, dolomite, greensand, glass sand, and ironbearing rocks that have been extensively investigated as a possible source of iron.

\section{INTRODUCTION}

The Trans-Indus Mountains of Pakistan, about $50 \mathrm{mi}$ south of Kohat (fig. 1), are a group of arcuate mountains lying west of the Salt Range and west of the Indus River (fig. 2). Individual ranges include the Surghar, Shinghar, Marwat, and Khisor (also spelled Khasor)

\footnotetext{
${ }^{1}$ Geological Survey of Pakistan
}

Ranges. The Makarwal coai field is in the Surghar Range, a well-defined series of ridges bounded by a prominent escarpment facing the Indus River. Another belt of parallel ridges west and north of the Surghar Range is called the Shinghar Range. These two ranges comprise the northern part of the Trans-Indus Mountains.

\section{PURPOSE AND SCOPE OF REPORT}

The geologic work discussed here was part of the mineral exploration and development effort undertaken by the Geological Survey of Pakistan (GSP) and the U.S. Geological Survey (USGS) under the auspices of the Government of Pakistan and the Agency for International Development, U.S. Department of State.

This report identifies and describes the sedimentary rocks of the area in order to provide the stratigraphic setting of economically important geologic formations. The stratigraphic terminology in this report employs the principles of the Stratigraphic Code of Pakistan in applying new names to unaccepted previous names in the literature. The distribution of these stratigraphic units is shown on the geologic quadrangle map (pl. 1). The distribution of coal beds and other rocks that have potential economic importance is shown in detail on large-scale maps. Special emphasis is placed on the geology of the Makarwal coal field, the most important mineral resource in this area.

The Makarwal coal field in recent years has yielded about a fifth of the coal production from Pakistan (fig. 1) and is the principal source of fuel for the cement and fertilizer factories at Daud Khel (fig. 2). Coal-using equipment of the Daud Khel industries is designed to specifications of the Makarwal coal, and the economy of this industrial area is dependent on the coal produced at Makarwal. To meet the continuing requirements of local industry, the Pakistan Industrial Development Corporation (PIDC) in 1957 embarked on a large-scale mine modernization program, which increased coal production at Makarwal by extending exploration to greater depths and to areas where new sources were inferred but not yet proven. 


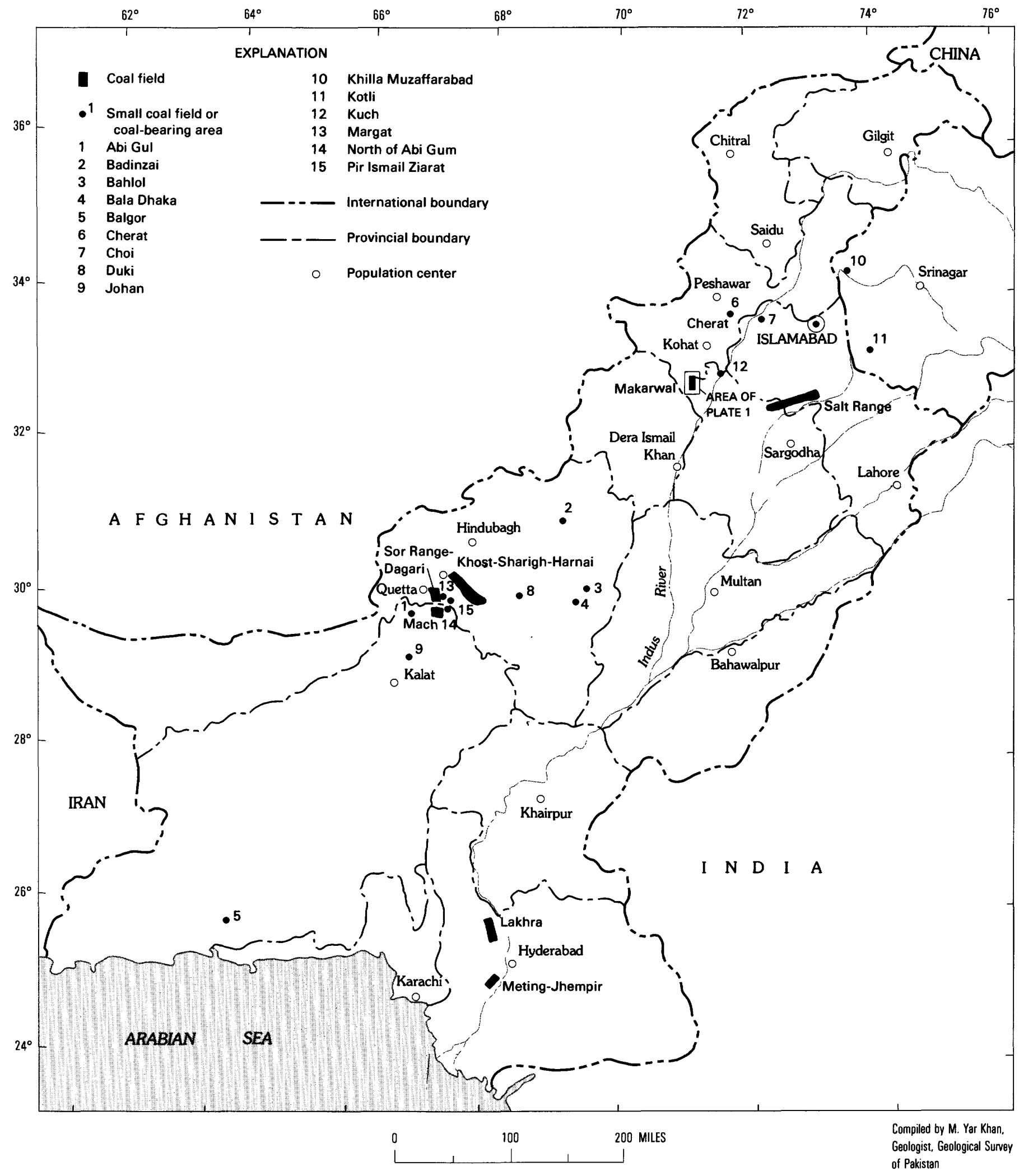

FIGURE 1.-Location of coal fields in Pakistan and the area of plate 1. 


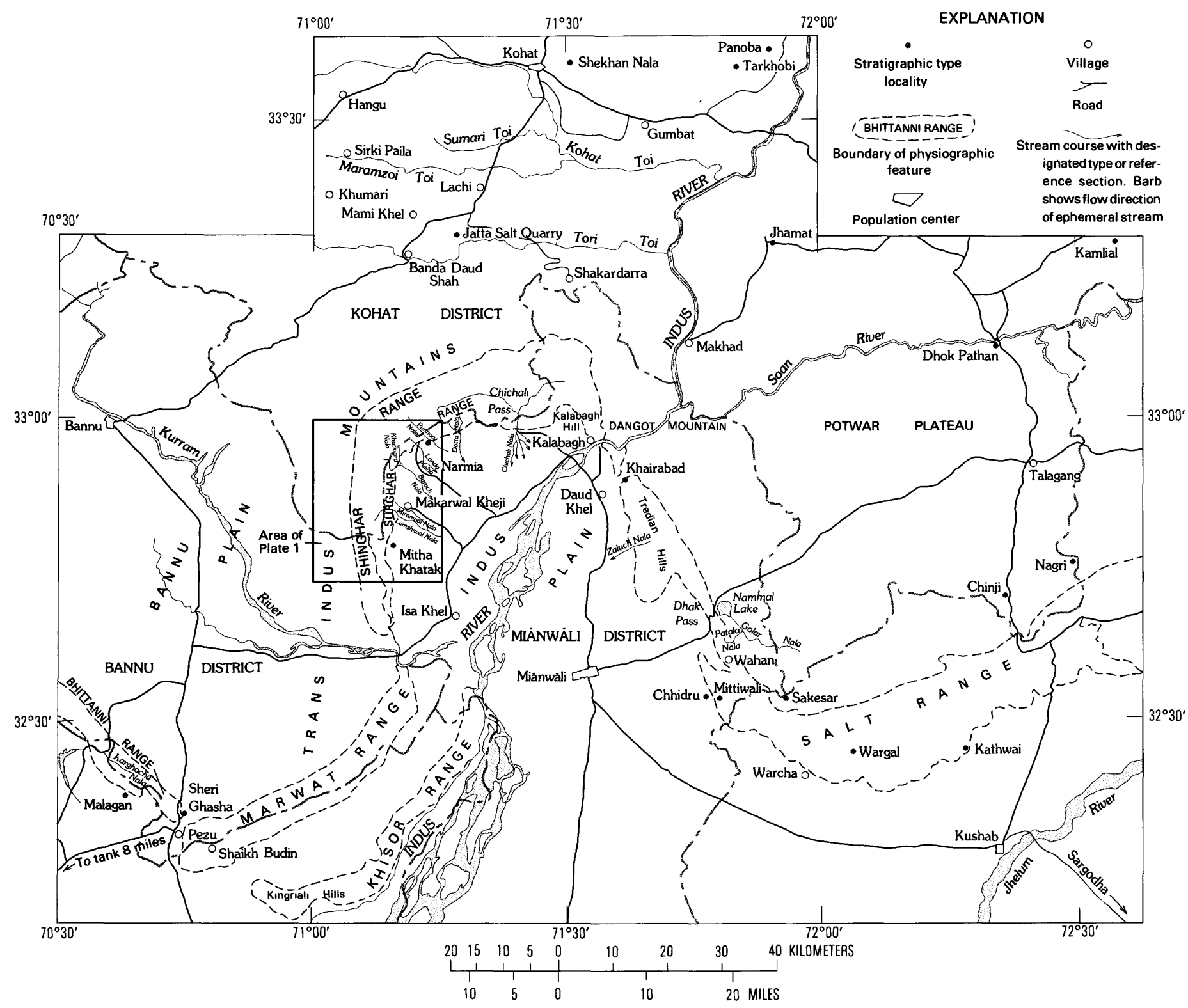

FIgURE 2.-Location of some cultural and topographic features mentioned in this report. Several formations that underlie the Trans-Indus Mountains and the western Salt Range are named for features in this area.

\section{TRANSPORT AND ACCESSIBILITY}

Travel to the mines is by the metalled Isa KhelKalabagh road (fig. 2) to the village of Kamar Mushani, and from there to Makarwal railroad station along another metalled road. A network of lorry roads leads to four mine-rail and ropeway terminals. Beyond these points, travel to the mine adits is by foot along steep trails half a mile or less.

The mined coal is lowered by ropeways from mine adits along the outcrop to mine railheads and lorry loading points for rail or motor transport to Makarwal station. It is transferred from the lorries and mine cars into rail cars on the meter-gauge spur of the Pakistan Western Railway and transported $34 \mathrm{mi}$ by rail to Daud Khel. Coal from the Gula Khel area (fig. 2), which includes the Landu, Punnoo, and Datta mines, is transported by lorry to Kamar Mushani, where it is loaded on rail cars.

\section{CLIMATE}

The field season for geologic mapping extends from October to April, when the humidity is low and mid-day 
temperatures range between $85^{\circ}$ and $95^{\circ} \mathrm{F}$. By midApril, the daytime temperature is nearly $100^{\circ} \mathrm{F}$., and during the summer months it exceeds $100^{\circ} \mathrm{F}$. for many days without relief.

The rainy season is during the summer months; heavy downpours provide temporary relief from the heat but are followed by an increase in humidity. The rains produce torrents that rush down the gorges carrying vast amounts of detritus. Travel and activity in these mountains during the rainy season may be dangerous because of floods and falling rock. Buildings and installations are constructed well above stream channels to prevent damage during floods.

\section{PREVIOUS GEOLOGIC WORK}

The earliest published comprehensive description of the geology of the Trans-Indus Mountains is by Wynne (1880); however, he made only passing reference to coal resources. Simpson's (1904) study of coal in the Makarwal area, which he called the "Maidan Range coal field," includes descriptions of the coal at all known sources between Kalabagh and Makarwal. Apparently, the coal had not been exploited at that time because Simpson recommended sites for development; these localities have been or now are being worked.

Gee (1938) described in detail the geology of areas that had been developed by 1938 . His report contains production figures (p. 292) indicating that coal was being mined as early as 1914. Gee's description of mines and mining problems is complemented by a report by Coulson (1938) on ground-water availability in the Isa Khel area. Coulson described the water problem in the Makarwal area and recommended ways of solving it.

\section{PRESENT INVESTIGATIONS}

Detailed geologic investigations of the Makarwal coal field and the surrounding area were carried out from March 1958 to February 1960. The work was done jointly by the GSP and the USGS, with assistance from the Pakistan Industrial Development Corporation (PIDC), operators of the coal mines at Makarwal. The investigations included detailed geologic mapping within the coal field and general geologic mapping of the area within the Makarwal quadrangle (Survey of Pakistan 1:50,000 scale topographic sheet $38 \mathrm{P} / 1$ ) which includes the coal field and nearby coal mines. Stratigraphic studies involved areas far beyond the quadrangle.

The base map used for detailed mapping of the coal field is a large scale $(1: 2,000)$ topographic map. The topographic base of the south part had been made by the Survey of Pakistan specifically for the operators of the coal mines. The topographic base of the north half was made by the GSP for the purposes of this study; the mapping was done in part by photogrammetry and in part by plane table and alidade.

Aerial photographs provided by the GSP were used in the geologic mapping of the Makarwal quadrangle. Mine maps, drill hole logs, and production data were provided by the PIDC Makarwal Collieries.

In this report, the name "Makarwal coal field" is applied to the area underlain by coal-bearing rocks in the vicinity of the village of Makarwal Kheji. The southernmost outcrop of coal-bearing rocks in the Surghar Range is about $1 \frac{1 / 2}{m i}$ south of Makarwal Kheji. The coal crops out along the east-facing escarpment of the Range and disappears less than $1 \mathrm{mi}$ northeast of Makarwal Kheji, making a total outcrop length of $2 \frac{1}{2} \mathrm{mi}$ (fig. 3). The coal-bearing rocks reappear farther north and can be followed along the escarpment northward and then eastward along the eastward along the easttrending part of the Surghar Range (fig. 3), a coal mining area referred to as the Gulakhel area.

\section{ACKNOWLEDGMENTS}

During the investigations for this report the management of the Coal Division of the Pakistan Industrial Development Corporation, operator of the Makarwal collieries, cooperated in every way. The authors especially wish to acknowledge the assistance and cooperation of Messdrs. W. Scherer and A. A. Malik, Chief Mining Engineers; Mr. W. Bettner, former Deputy Chief Mining Engineer of the colliery; and Mr. S. Hamid Hussain, colliery Manager. Mr. S. H. Faruqi, Senior Geologist, Pakistan Industrial Development Corporation, provided stratigraphic and geologic information and assisted in topographic mapping of the southern part of the coal field. Mr. N. A. Bhatti, Assistant Director, Geological Survey of Pakistan, measured the coal in underground workings.

\section{STRATIGRAPHY}

\section{CLASSIFICATION OF FORMATIONS}

The classification and terminology used for rock formations in the Trans-Indus Mountains were derived from the stratigraphic names of equivalent units in the Salt Range and the Potwar Plateau, where the earliest geologic work in this region was done. The early workers applied descriptive names to many of the formations, partly for informal usage, but also because that was the accepted practice of identifying formations at that time. Some formations were given geographic names without any apparent reason except, perhaps, that the unit may have been otherwise nondescript. In at least two cases, the same geographic name was given to two formations of different lithology. 
STRATIGRAPHY

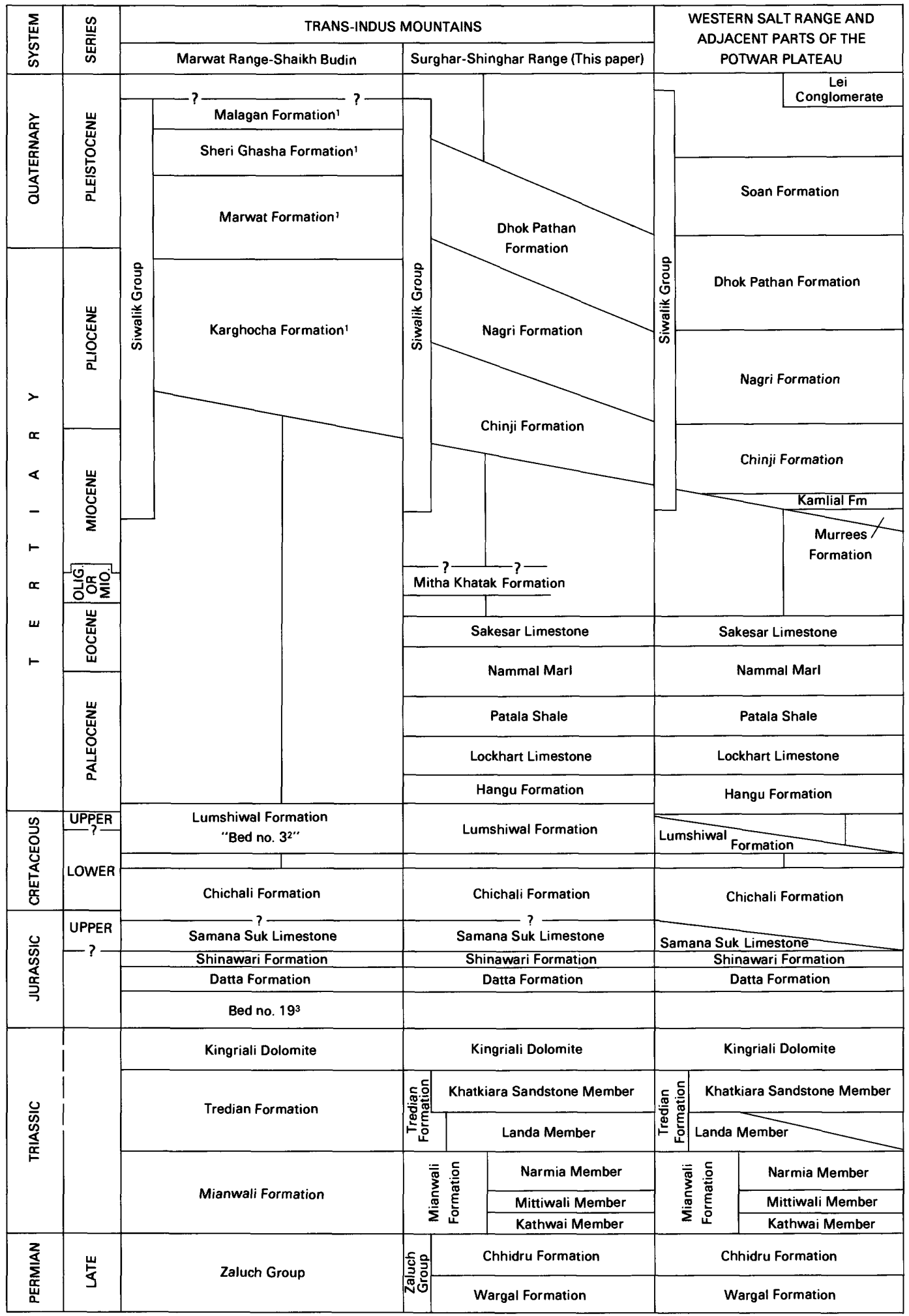

1 Morris, 1938

2 Wynne, 18BO, p. 81

${ }^{3}$ Wynne, 1BBO, p. 70

FIGURE 3.-Correlation of formations in the Trans-Indus Mountains and the western Salt Range, Pakistan. 
TABLE 1.-Stratigraphic sequence and lithostratigraphic classification of rocks in the western Salt Range and Trans-Indus Mountains, Pakistan

\begin{tabular}{|c|c|c|c|c|c|c|c|}
\hline \multirow{2}{*}{$\sum_{\substack{w \\
s}}^{\frac{5}{s}}$} & \multirow{2}{*}{ 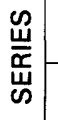 } & \multirow{2}{*}{\multicolumn{2}{|c|}{$\begin{array}{l}\text { Gee's (1945) classification } \\
\text { WESTERN SALT RANGE }\end{array}$}} & \multicolumn{4}{|c|}{ Proposed lithostratigraphic classification (Trans-Indus Mountains) } \\
\hline & & & & SURGHAI & R-SHINGAR RANGE (this paper) & & ARWAT-KHISOR RANGE \\
\hline 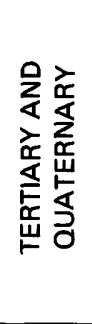 & & 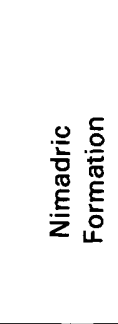 & 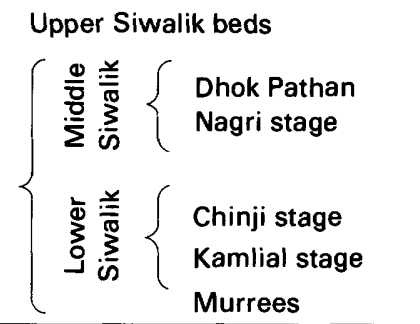 & \multicolumn{2}{|l|}{ 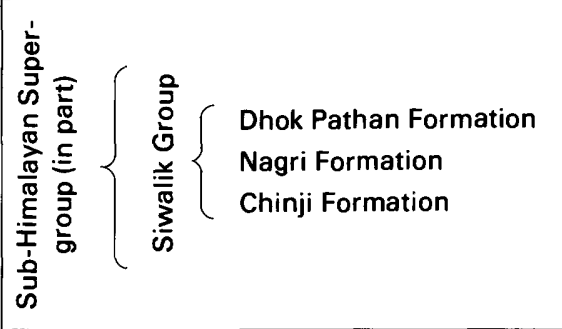 } & 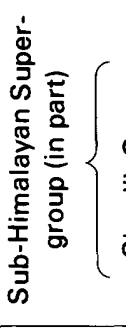 & 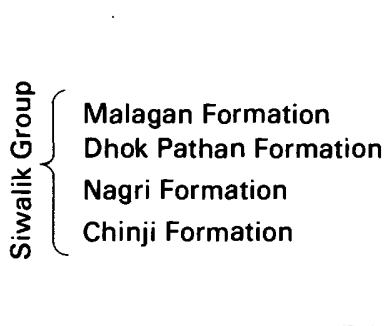 \\
\hline 㴶 & & 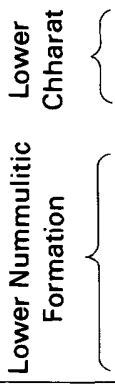 & $\begin{array}{l}\text { Red claybeds } \\
\text { Kohat saline series } \\
\text { Bhadrar beds } \\
\text { Sakesar limestones } \\
\text { Namal limestones and shales } \\
\text { Patala shales } \\
\text { Khairabad limestones } \\
\text { Dhak Pass beds } \\
\end{array}$ & & $\begin{array}{l}\text { Mitha Khatak Formation } \\
\text { Sakesar Limestone } \\
\text { Nammal Marl } \\
\text { Patala Shale } \\
\text { Lockhart Limestone } \\
\text { Hangu Formation (includes } \\
\quad \text { Makarwal coal bed) }\end{array}$ & & \\
\hline 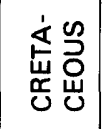 & & \multicolumn{2}{|r|}{$\begin{array}{l}\text { Lumshiwal sandstone } \\
\text { Belemnite beds }\end{array}$} & \multicolumn{2}{|r|}{ Lumshiwal Formation } & \multicolumn{2}{|r|}{ Chichali Formation } \\
\hline$\stackrel{\frac{u}{5}}{\rightrightarrows}$ & & \multicolumn{2}{|r|}{$\begin{array}{l}\text { Baroch limestone } \\
\text { Variegated stage }\end{array}$} & & $\begin{array}{l}\text { Samana Suk Limestone } \\
\text { Shinawari Formation } \\
\text { Datta Formation }\end{array}$ & \multicolumn{2}{|r|}{$\begin{array}{l}\text { Samana Suk Limestone } \\
\text { Shinawari Formation } \\
\text { Datta Formation }\end{array}$} \\
\hline 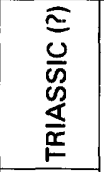 & & \multirow{2}{*}{\multicolumn{2}{|c|}{$\begin{array}{l}\text { Kingriali dolomites } \\
\text { Kingriali sandstones }\end{array}$}} & \multirow{2}{*}{ 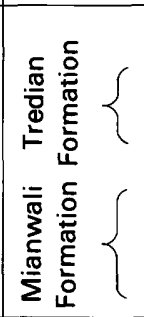 } & $\begin{array}{l}\text { Kingriali Dolomite } \\
\text { Khatkiara Sandstone Member } \\
\text { Landa Member }\end{array}$ & \multicolumn{2}{|r|}{$\begin{array}{l}\text { Kingriali Dolomite } \\
\text { Tredian Formation }\end{array}$} \\
\hline 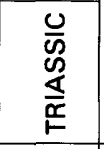 & & & & & $\begin{array}{l}\text { Narmia Member } \\
\text { Mittiwali Member } \\
\text { Kathwai Member }\end{array}$ & & Mianwali Formation \\
\hline \multirow{2}{*}{ 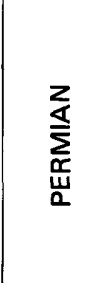 } & $\begin{array}{l}\frac{a}{4} \\
\frac{u}{0} \\
\frac{0}{5} \\
\end{array}$ & \multicolumn{2}{|r|}{ Productus limestone series } & 동 을 & $\begin{array}{l}\text { Chhidru Formation } \\
\text { Wargal Formation }\end{array}$ & $\begin{array}{l}\frac{5}{0} \\
\frac{3}{\pi} \\
\text { N }\end{array}$ & $\begin{array}{l}\text { Chhidru Formation } \\
\text { Wargal Formation } \\
\text { Amb Formation }\end{array}$ \\
\hline & 䍃 & \multicolumn{2}{|r|}{$\begin{array}{l}\text { Lavender clays } \\
\text { Speckled sandstone } \\
\text { Conularia Beds } \\
\text { Talchir boulder beds }\end{array}$} & & & 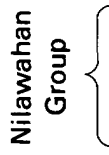 & $\begin{array}{l}\text { Sardi Shale } \\
\text { Warcha Sandstone } \\
\text { Dandot Formation } \\
\text { Tobra Formation }\end{array}$ \\
\hline 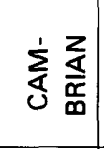 & & & & & & 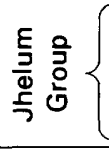 & $\begin{array}{l}\text { Khisor Formation } \\
\text { Jutana Dolomite } \\
\text { Kussak Formation } \\
\text { Khewra Sandstone }\end{array}$ \\
\hline 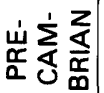 & & \multicolumn{2}{|r|}{ Punjab saline series } & & Salt Range Formation & \multicolumn{2}{|r|}{ Salt Range Formation } \\
\hline
\end{tabular}


According to the principles of stratigraphic classification recommended in the Stratigraphic Code of Pakistan (Stratigraphic Nomenclature Committee of Pakistan, 1962), lithostratigraphic units, including bed, member, formation, group, and supergroup, are to be named after an appropriate geographic feature in a designated type area. The English spelling of place names applied to newly designated formations is taken from the spelling given on Geological Survey of Pakistan topographic sheets, typographic errors excepted. The original spelling of place names applied for formations by earlier writers is preserved, even though present spelling may differ. This practice is recommended because spelling, and even pronunciation, of certain place names periodically undergoes slight change. Exceptions to this recommendation may be made in cases of obvious misspelling of geographical names by original authors.

The prevailing classification of formations in the Trans-Indus Mountains, that of Gee $(1945$, pl. I), is given in table 1 along with the classification used in this paper. Correlation of formations in the Trans-Indus Mountains and western Salt Range is shown in figure 3; the idealized stratigraphic relationships are shown in figure 4. Some of the formations, particularly the prePermian and Lower Permian ones that are incompletely exposed or being investigated by other workers elsewhere, are not discussed here but are listed in table 1 for the sake of completeness. These latter units are most extensive in the eastern Salt Range, outside the area of this report.

During the interval between the writing and publishing of this report, stratigraphic nomenclature in Pakistan has been under review by the Stratigraphic Nomenclature Committee of Pakistan. In the course of these reviews, some of the formation names proposed in this report have been adopted by the Committee. The approved names are binomial and consist of a geographic name and lithologic rank or name; both terms are capitalized. The names Mitha Khatak Formation, Kalabagh Hill Conglomerate, and Malagan Formation have not yet been formally accepted but are believed to meet the requirements of the code. Previously-used stratigraphic names that have been supplanted or that do not meet the requirements of the code are distinguished by the uncapitalized rank name or, where necessary for clarity, by use of quotation marks. Informal rock units are distinguished in the same manner.

The oldest rocks in the Trans-Indus Mountains are Precambrian in age (table 1). Rocks younger than Paleocene predominate; those of Paleocene age include the coal-bearing formation. The rocks that crop out within the area covered by the detailed geologic map of the coal field (pl. 2) range in age from Jurassic to Holocene. The lithology and average thickness of these rocks are shown in figure 5 .

PERMIAN SYSTEM, UPPER PERMIAN SERIES

\section{ZALUCH GROUP}

The name Zaluch Group, in accordance with recommendations of the Stratigraphic Nomenclature Committee of Pakistan (written commun., 1968), replaces the descriptive name "Productus limestone" given by Waagen (1889) to the prominent upper Paleozoic limestone in the Salt Range.

Gee (1945, pl. 1) called this limestone a series (table 1) in the sense of a lithostratigraphic group - a usage that prevailed at the time - and he recognized three constituent units, the lower, middle, and upper Productus beds. These units have not been differentiated in the Trans-Indus because complete sections of the Zaluch Group along the east flank of the Khisor Range were not studied in detail by the authors, and only the upper and middle units of the Zaluch Group are exposed in the Surghar Range. These units are now called the Wargal and overlying Chhidru Formations by the Stratigraphic Nomenclature Committee of Pakistan (written commun., 1968); the type localities are in the Salt Range (fig. 2).

Only the Wargal and Chhidru Formations crop out within the Makarwal quadrangle. The formations were mapped together because the exposures along cliffs of the middle unit, the Wargal, are not thick enough to show on the scale of the quadrangle map (pl. 1).

The Wargal Formation is very pale brown, very thick bedded, dense limestone that contains abundant colonial corals. The exposed thickness in the quadrangle is estimated to exceed $90 \mathrm{ft}$. The Chhidru Formation consists of light-gray, dense, nodular sandy limestone. The unit contains carbonaceous shale that is interbedded with nodular limestone rich in fossils. The upper part of the Chhidru is very sandy, fossil-rich limestone that corresponds to the Bellerophon beds of Wynne (1880, p. 78). The thickness of the Chhidru is estimated to be $225 \mathrm{ft}$.

\section{TRIASSIC AND TRIASSIC(?) SYSTEMS}

MIANWALI FORMATION

The Mianwali Formation, named for Mianwali District, is here used to refer to the Triassic rocks formerly identified (Gee, 1945) in the Salt Range by the descriptive name "Ceratite beds," and to younger formations of Triassic age in the Surghar Range that resemble the "Ceratite beds" and have a similar depositional history. In the Surghar Range, Kummel (1966) 


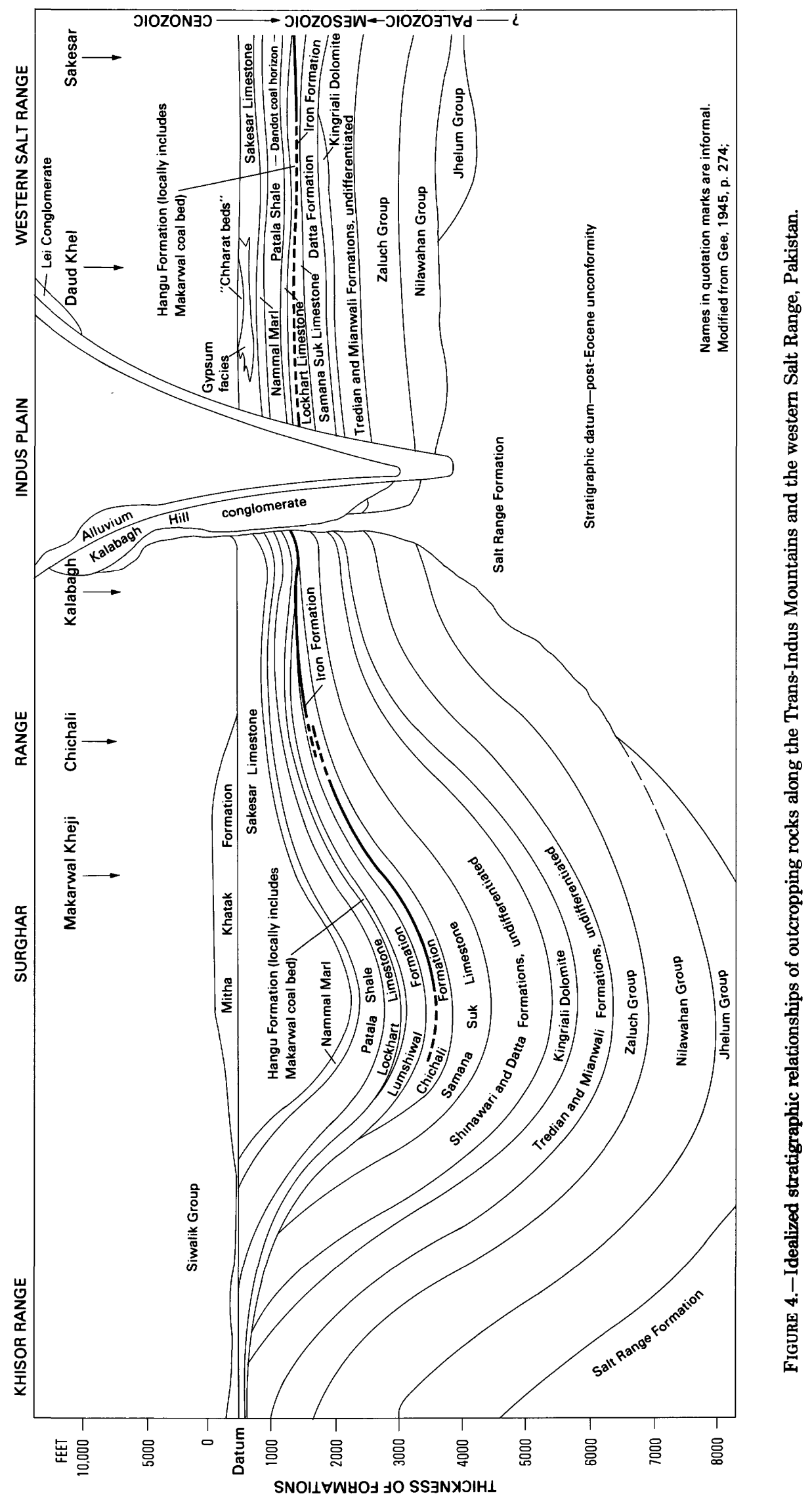


STRATIGRAPHY

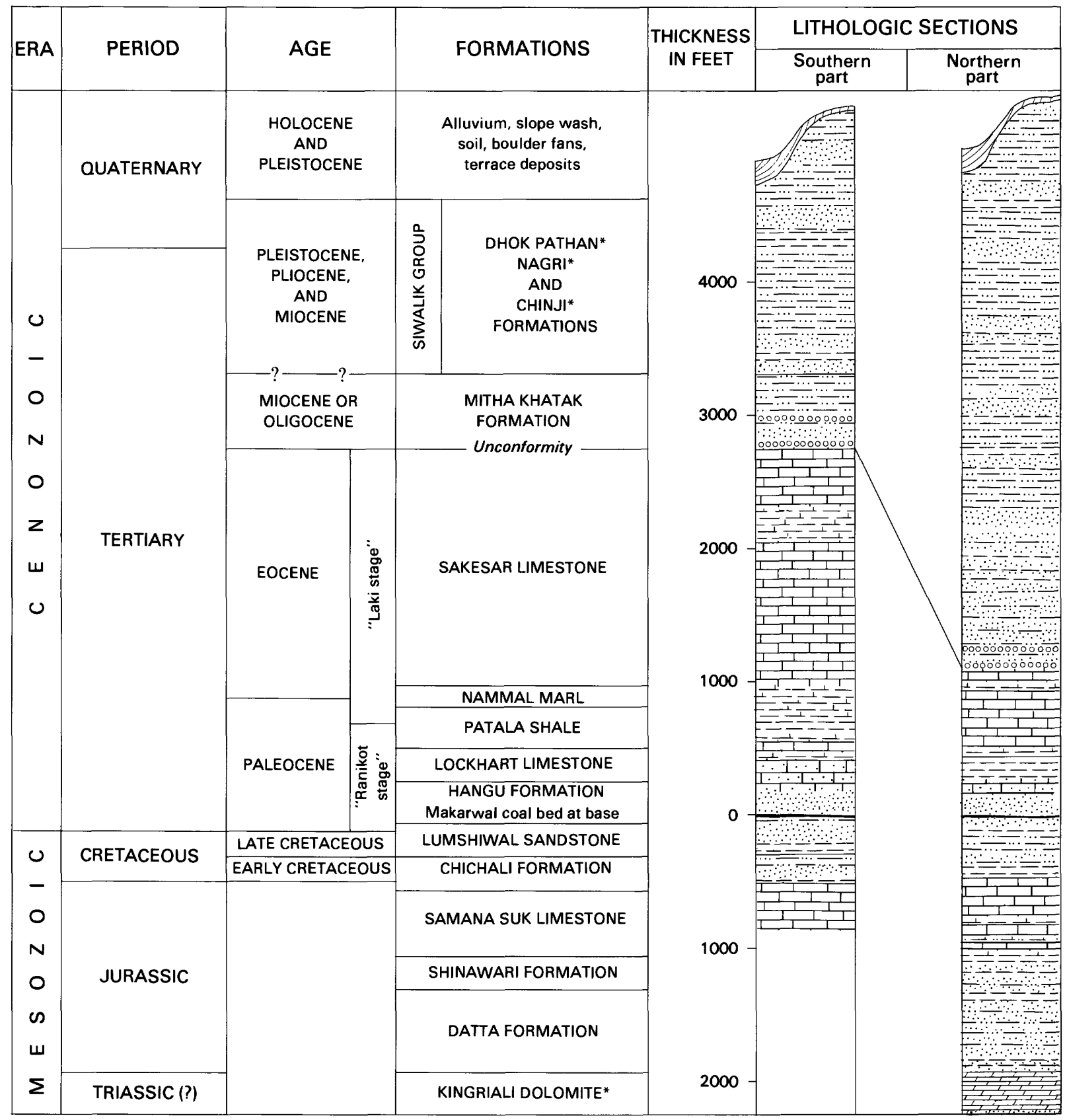

\section{EXPLANATION}

\begin{tabular}{|l|l}
\hline 000000 & Conglomerate \\
\hdashline & Sandstone \\
\hdashline & \\
\hdashline & Siltstone \\
\hline &
\end{tabular}

Calcareous claystone

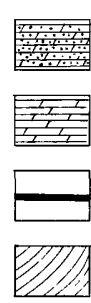

Sandy dolomite

Dolomite

Coal

Alluvial deposits, undifferentiated

*Formations not exposed within coal field

FIGURE 5.-Stratigraphic section of rocks exposed in the area covered by the detailed geologic map of the Makarwal coal field. 
divided these rocks into three members, in ascending order, the Kathwai, Mittiwali, and Narmia.

The name Mianwali was first used by Gee (in Pascoe, 1959 , p. 582, as "Mianwali Series") to include all the Triassic and probable Triassic rocks in the Salt and Khisor Ranges that ". . . on stratigraphic grounds are linked with the underlying Ceratite beds as part of the Triassic sequence." However, the three members named by Kummel comprise a lithologically related group distinctly different from the younger rocks of Triassic or probable Triassic age. Therefore, the term is here modified from Gee's time-stratigraphic usage and restricted to the lithostratigraphic unit that includes the Kathwai, Mittiwali, and Narmia Members of Kummel.

The Kathwai Member forms a thin but distinctive outcrop of grayish-orange dolomite that contains some laminated limestone. The unit was named for a locality in the Salt Range. The measured thickness of the member at the type locality is $7^{1 / 2}$ feet (Kummel, 1969, p. 375).

The Mittiwali Member also was named for a locality in the Salt Range. It consists of dark-gray to black shale, containing abundant laminated siltstone and sandstone beds that are interbedded at random intervals. Thin beds of gray, fine-grained limestone containing ammonites are evenly distributed within the member. The member is $487 \mathrm{ft}$ thick at Narmia (pl. 1) according to Kummel (1968, p. 377); elsewhere within the quadrangle it appears to thin to an estimated thickness of $215 \mathrm{ft}$.

The uppermost member, the Narmia, consists of darkgray to black shale that contains thin ammonite-bearing limestone beds. The topmost bed of the Narmia Member is a layer of pisolitic limestone 7 to $12 \mathrm{ft}$ thick. It is laterally persistent and forms an unmistakable stratigraphic key or marker bed, but outcrops are inconspicuous; the lithologically and visually similar rocks above and below the pisolitic bed cannot be separated at the map scale of $1: 50,000$ or smaller. The total thickness of the member is $140 \mathrm{ft}$ measured at the type locality near Narmia village (Kummel, 1968, p. 380).

The Landa Member of the overlying Tredian Formation was mapped with the underlying Mianwali Formation because the units cannot be easily differentiated in the field.

Fatmi (1972, p. 311) considers the Mianwali Formation to be Early Triassic in age.

\section{TREDIAN FORMATION}

The Tredian Formation is a new name that has been approved by the Stratigraphic Nomenclature Committee (written commun., 1968) to replace Gee's (1945, p. 272) Kingriali sandstones. Gee had also applied the same geographical name to the overlying formation, the
Kingriali Dolomite. Because the Stratigraphic Code of Pakistan requires that one of these two units be renamed, the lower of the two, the sandstdones, is included in a unit named the Tredian Formation (Gee, in Kummel, 1966, p. 374).

The formation is divisible into two lithologically contrasting units. The lower part was named Landa Member by Kummel (1966, p. 380) after Landa Pusha; the type locality of the member (lat $32^{\circ} 57^{\prime} \mathrm{N}$., long $71^{\circ} 11^{\prime} 50^{\prime \prime}$ E.) is in the Surghar Range. Kummel described the member as consisting of black, pink, or red micaceous sandstone and black sandy micaceous shale containing poorly preserved fragmentary plant remains. The sandstone and shale, present in nearly equal proportions, are thin to very thick bedded and have ripple marks, slump, and cut-and-fill structures. Thin interbeds of siltstone are present. In Landa Pusha, and in the northeast part of the Makarwal quadrangle, the member is $97 \mathrm{ft}$ thick. The Landa Member is lumped with the underlying Mianwali Formation in plate 1 because the units are difficult to distinguish in the field.

The upper part is named the Khatkiara Sandstone Member for Khatkiara Nala (lat $32^{\circ} 56^{\prime}$ N., long $71^{\circ} 11^{\prime}$ E.), misspelled Khalkiara on [Geological] Survey of Pakistan topographic sheet $38 \mathrm{P} / 1$. The member corresponds to the sandstone identified by Wynne $(1880$, p. 70) as bed No. 17 .

The Khatkiara Sandstone Member consists of lightyellowish-gray, thin- to thick-bedded, crossbedded sandstone that contains fine- to very fine subangular grains. The lowermost beds of sandstone are deeply iron oxide stained with conspicuous mottling of red and yellow. The member is dolomitic in the upper part and contains carbonaceous siltstone and clay shale in the middle and lower parts. The member is less resistant to erosion than the overlying formation and is commonly well exposed at the base of waterfalls developed on the overlying dolomite. Bedding in the basal beds is highly convoluted and irregular. The thickness of the Khatkiara is $135 \mathrm{ft}$ in Khatkiara Nala and ranges to as much as $165 \mathrm{ft}$.

The age of the Khatkiara Sandstdone Member is probably Triassic. One sample of carbonaceous shale from a layer $36 \mathrm{ft}$ above the base of the formation yielded a good assemblage of plant microfossils. Concerning these, R. A. Scott (palynologist, U.S. Geological Survey, written commun., 1964) stated the following:

The pollen assemblage contains extinct striate bisaccate forms, representing the genus Taeniaesporites, probably Striatopodocar pites, and possibly additional striate genera. In the United States and Europe these striate bisaccate pollen grains, common in Permian and Triassic rocks, are not found above the Triassic. However, there is one putative record of the striate bisaccates from the Jurassic of India, but the correctness of this age determination has been questioned by other workers. Because of the questioned Indian report, and in the 
absence of any local control material of our own, I would regard the age of these fossils as most probably Triassic, but would consider this assignment as tentative until the upper range of the striate bisaccates of India has been established without doubt.

Fatmi $(1973$, p. 26) gives an age of Middle(?) Triassic for the Tredian.

The Khatkiara Sandstone Member is well exposed on the flanks of an anticline that extends along Khatkiara Nala, and is described in the following section:

Type section of Khatkiara Sandstone Member of the Tredian Formation measured in Khatkiara Nala

\section{Triassic(?):}

Kingriali Dolomite:

10. Dolomite, grayish-orange-pink, massive, closely jointed, in part oolitic textured, in part por-

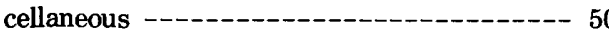

Tredian Formation:

Khatkiara Sandstone Member:

9. Sandstone, light-yellowish-gray, fine-grained, dolomitic --_-_-_-_-_-_ 8

8. Dolomite, brownish-gray, dense ---.------- 4

7. Sandstone, light-yellowish-gray, thin-bedded, even-bedded, fine-grained --------------- 10

6. Dolomite, light-brown, thin-bedded, dense, sandy near base and gradational to unit below --_--_-_-_-_-_- 3

5. Sandstone, light-yellowish-gray to very light gray, thick-bedded, cross-bedded, very fine to fine-grained, very well sorted, subangulargrained --.----_-_- 39

4. Sandstone, yellowish-gray, thin-bedded to lenticularly platy, very fine grained; interbedded with dark-gray carbonaceous siltstone and coaly shale laminae ---.---------------- 6

3. Sandstone, light-gray, thin-bedded, finegrained; contains scattered small ironstone

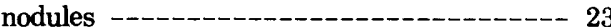

2. Siltatone and clay shale interlaminated with carbonaceous claystone; lenticular, doubling in thickness within $50 \mathrm{ft}$------.---.---

1. Sandstone, light-yellowish-gray, very thick bedded, very fine grained -.--_-_-_-_-_-_- 41

Total thickness of Khatkiara Sandstone Member

Thickness
Ft In.

4

3

39

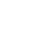

23

16

Landa Member:

0. Interbedded siltstone, sandstone, and shale, reddish-gray to medium-dark-gray, platy, finely laminated in siltstone layers --.----- $10+$

\section{KINGRIALI DOLOMITE}

The term Kingriali Dolomite was first mentioned in the literature (as "Kingriali dolomites") by Gee (1945, table 1 and p. 277). The name was taken from the Kingriali Hills (fig. 2) at the southern end of the Khisor Range (lat $32^{\circ} 12^{\prime} \mathrm{N}$., long $71^{\circ} 00^{\prime} \mathrm{E}$.) where the formation forms a prominent cliff. Although not designated

so, it may be assumed that the Kingriali Hills are the intended type locality of the Kingriali Dolomite. The use of the lithologic term dolomite is appropriate for the formation in the Surghar Range and wherever the unit is predominantly dolomite. This should not preclude changing the name to formation in other areas where lithologic variation warrants such a change, provided that the geographic term is retained (American Commission on Stratigraphic Nomenclature, 1961, p. 654).

The Kingriali Dolomite in the Surghar Range is a massive, cliff-forming formation uniform in lithology. The rock is grayish orange pink, much jointed, porcellaneous to flintlike. The lower part of the formation is a very thick bedded dolomitic limestone that is typically very brecciated. In the upper part, the formation is thin to medium bedded and marly; the middle part is very thick bedded, saccharoidal, and low in calcite content. The upper contact of the formation is sharp and is marked by a lateritic bed several inches thick; the lower contact is also sharp. The formation is $323 \mathrm{ft}$ thick in the western part of the range; the following reference section was measured in the Punnoo mines area (pl. 1).

\section{Reference section of Kingriali Dolomite measured in Punnoo Nala} (lat $32^{\circ} 28^{\prime} N$., long $71^{\circ} 13^{\prime} E$.)

Jurassic:

Datta Formation:

11. Sandstone, very light gray, very thick bedded; grains fine to angular ---------------- 27

Triassic(?):

10. Lateritic clay, grayish-red, blocky -.-_-_-_- 01

Kingriali Dolomite:

9. Dolomite, dark-yellowish-brown, thin-bedded; crumbly; calcareous; irregular blocky fracture

8. Dolomite, dark-grayish-orange; weathers yellowish orange; beds to $2 \mathrm{ft}$ thick, calcareous ----- 15

7. Dolomite, light-grayish-orange, thin beds alternating with medium beds, dense, brittle ----- 39

6. Dolomite, light-yellowish-brown, thin-bedded -- $18 \quad 6$

5. Covered interval, but underlain by grayishorange-pink dolomite; dense crystalline texture --

4. Dolomite, grayish-orange-pink, finely saccharoidal, porous, thick-bedded, calcareous --_-- 85

3. Dolomite, very pale yellowish brown, thin bedded in lower $10 \mathrm{ft}$, very thick bedded and brecciated in upper $60 \mathrm{ft}$-.-- 71

2. Sandstone, dusky-yellow, calcareous --_------ 8

1. Dolomitic limestone, pale-yellowish-brown; thin fossiliferous beds contain abundant brachiopod shells and pentagonal crinoid remains --- 41 Total thickness of Kingriali Dolomite $\quad \begin{array}{lll}0 & 0\end{array}$

Tredian Formation: Khatkiara Sandstone Member:

0 . Light-gray sandstone 100

In the Khisor Range, Wynne $(1880$, p. 70$)$ mentions that bed No. 18, which probably corresponds to the 
Kingriali Dolomite of the Surghar Range, is overlain by bed No. 19, which is thin-bedded, white dolomitic limestone alternating with white marl containing cephalopods and crinoids. Bed No. 19 is apparently not present in the Salt and Surghar Ranges, and it must be assumed that Gee transferred the term Kingriali to the Salt Range and applied it only to the equivalent of bed No. 18 of Wynne.

Gee (1945) considered the age of the Kingriali Dolomite to be Jurassic and Triassic. However, Wynne (1880) regarded bed No. 18 to be of probable Triassic age and bed No. 19 to be of Jurassic age. Fatmi (1972, p. $311)$ gives the age as Late(?) Triassic. For the present, therefore, the age of the Kingriali Dolomite of the Surghar Range is referred to as Triassic(?) on the assumption that bed No. 19 is not present in the Surghar Range.

\section{JURASSIC SYSTEM}

\section{DATTA FORMATION}

The name Datta Formation is introduced here to replace the descriptive name Variegated Series or stage of earlier authors. The Datta is named for Datta Nala (fig. 2), also locally referred to as Sodhri Nala, which flows along the road leading to the Datta coal mines (lat $33^{\circ} 00^{\prime}$ N., long $71^{\circ} 19^{\prime}$ E.).

The Datta Formation consists of alternating layers of sandstone and shale in thick, varicolored beds. The sandstone is medium to fine grained, commonly very thick bedded, and contains interbedded carbonaceous siltstone.

Thick beds of light-gray to white sandstone form distinctive white outcrops especially where white efflorescences of soluble salts are deposited on the surface of exposed sandstone. The Datta contains thin coaly lenses that were formerly mined at Kuch near Kalabagh (fig. 2).

The lower contact is sharp, the base marked by a lateritic claystone less than an inch tilick over wide areas, to several feet thick in some places. The contact is a disconformity, as reported by Fatmi $(1972$, p. 312$)$. The total thickness of the Datta ranges from 550 to 700 $\mathrm{ft}$ in the mapped area.

Fatmi (1972, p. 313-315) reports that Pascoe (1959) has recorded Bouleiceras sp. from the Sheikh Budin hills; Fatmi, however, did not find the ammonites in the Trans-Indus. In other areas (West Kohat and Hazara) Bouleiceras sp. is present, and on this basis the Datta is of Early to Middle Jurassic age (mainly Toarcian, Fatmi, 1972, p. 314, 315).

\section{SHINAWARI FORMATION}

The rocks that form a transition zone between the Datta and the overlying Samana Suk Formation were correlated with similar rocks in the Samana Range, Kohat District, by Fatmi (1973, p. 30), who named them the Shinawari Formation. In the Makarwal area thin beds of dusty-yellowish-brown limestone to thick beds of gray shale and sandstone comprise the Shinawari Formation. A thick bed of red shale and an underlying thin bed of calcareous claystone near the bottom of the Shinawari are prominent and persistent, traceable throughout its outcrop extent in the Surghar Range.

The age of the Shinawari is Early to Middle Jurassic.

Descriptions of the Shinawari are given in the following two sections:

Section of Shinawari Formation and type section of Datta Formation measured in Datta Nala

Jurassic:

Shinawari Formation:

77. Shale, grayish-blue; upper part is more marly than the lower; lower part contains maroon sandstone beds; thin to medium bedded, fine to medium grained; the base of this unit is a bed of yellowish-gray shale that is fissile and soft -..---

76. Shale, dark-blue, silty-fissile, and soft --.-------

75. Sandstone, brownish-red, medium- to coarsegrained, slightly calcareous, very hard, oolitic ---

74. Shale, reddish-brown (maroon) --_---

73. Sandstone, white, fine-grained, silty -----------

72. Shale, reddish-brown (maroon), soft and fissile, persistent over the area; contains thin beds of white sandstone; silty --

71. Sandstone, grayish-orange-pink; weathers to grayish pink; light-red bands; brownish-red inclusions in the lower part; medium to coarse grained, rounded to subrounded, very thick bedded; cliff forming

70. Shale, pale-brown (maroon), friable, soft --..--

69. Limestone, bluish-gray with white streaks, richly

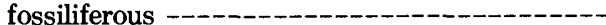

68. Marlstone, blue; weathers to yellowish brown; brittle; kidney shaped on weathering --.-----Total thickness of Shinawari Formation

Datta Formation:

67. Siltstone, dark-gray; weathers to yellowish gray; fine-grained plates of calcareous material found at fresh surface, hard --------

66. Siltstone, grayish-white; weathers pinkish white to gray; fine grained; very thick bedded ------- 15

65. Shale, gray, calcareous ------

64. Siltstone, gray; contains shale beds in the upper part and the rest is covered ---_------

63. Sandstone, grayish-blue; weathers to grayish yellow; fine grained, thick bedded, hard ---.---

62. Shale, blue, friable --

61. Siltstone, bluish-white; weathers to rusty red with grayish patches; thick bedded -------

60. Shale; general color is reddish brown with blue, white, gray and red patches; very friable, marly -

59. Sandstone, pinkish-white, medium- to fine-grained, very thick bedded; cliff forming; lower part grades into medium-bedded siltstone --..--.---- 
58. Mudstone, reddish-brown (maroon), friable at the surface; persistent, found throughout the region; contains white streaks or bands --.--.---

57. Siltstone, bluish-white; lower part weathers to

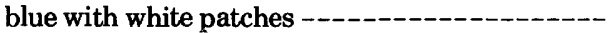

56. Mudstone, reddish-brown (maroon), friable --------

55. Siltstone, dark-blue; weathers to rusty red; lower part is mudstone; very friable -...-..---.---

54. Siltstone, greenish-white; weathers to pinkish yellow - -

53. Mudstone, reddish-brown (maroon); upper part fri-

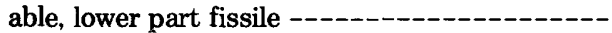

52. Sandstone, pinkish-white, medium- to coarse grained; subangular grained, very thick bedded;

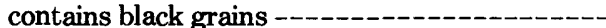

51. Siltstone, reddish-brown (maroon) -------------

50. Siltstone, pinkish-white; weathers to grayish pink ---------------------------

49. Shale, bluish-white, spotted with blue and white;

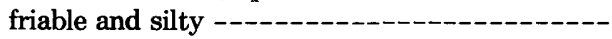

48. Siltstone, pinkish-white, massive, one layer only --

47. Shale, white and yellow, mottled with blue, friable; middle layer is harder than the other two, silty --_---_-

46. Sandstone, grayish-white; weathers to pinkish yellow; fine grained with silty matrix; grades downward into coarse grain and very coarse grain; very thick bedded; surface is banded with white

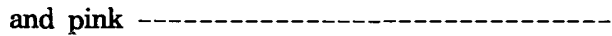

45. Shale, multicolored (greenish white, mottled with blue), friable; thin bedded and silty; middle part is pinkish-white siltstone

44. Sandstone, grayish-orange-pink, fine to mediumgrained, silty matrix; medium thick to very thick bedded -

43. Sandstone, pinkish-gray; weathers to yellowish pink; medium grained with silty matrix; hard regular bedded and massive; forms vertical cliffs, persistent; abundant colored minerals are

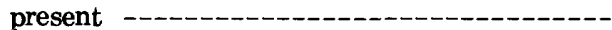

42. Sandstone, white; weathers to grayish white; fine grained, thick bedded; lower part friable and

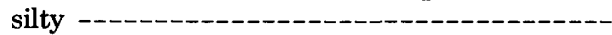

41. Mudstone, upper 22 in. blue with white patches, thin bedded, friable; lower 34 in. pinkish white with blue patches, medium bedded; silty; per-

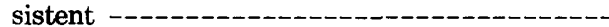

40. Mudstone, dark-reddish-purple (violet), friable, persistent -.----

39. Siltstone, white, persistent -_-

38. Sandstone, pinkish-grayish-white; weathers to yellowish gray; very fine grained to fine grained, very thick bedded; cliff forming; lower 27 in. silty sandstone, soft, contains 5-inch-thick band of sandy mudstone

37. Sandstone, light-grayish-pink, fine-grained; coarse grains of black mineral abundant; soft --------

36. Mudstone, grayish-red, irregularly banded with white streaks; silty --_-_-_-_-

35. Sandstone, pinkish-white, medium- to coarsegrained; subrounded to subangular grains, loose silty matrix; abundant grains of black material resistant to weathering stand upright on the surface
34. Mudstone and siltstone, reddish-brown (maroon), very thin bedded, regularly bedded; fossile, upper part very friable and soft ----------_----

33. Sandstone, pinkish-white, medium- to finegrained;

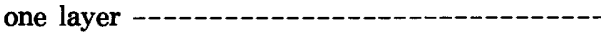

32. Sandstone, blue to green; contains alternate layers of mudstone and pinkish-white siltstone spotted with brown weathered minerals ---.---.

31. Siltstone, grayish-pink, fine-grained, thick-bedded

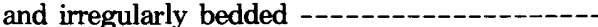

30. Mudstone, dark-reddish-purple (violet) --_-------

29. Sandstone, grayish-pink, very fine grained --------

28. Mudstone, dark-reddish-purple (violet), friable ----

27. Siltstone, grayish-white --_----_------

26. Mudstone, greenish-blue; weathered surface is violet; friable; thin to medium bedded, silty --.----

25. Sandstone, pinkish-white, fine-grained, very thin bedded; black minerals present --_--_-_-_-_- $8 \quad 8 \quad 10$

24. Mudstone, dark-grayish-purple (violet) --_-_-_-_-. $\quad 5 \quad 2$

23. Siltstone, grayish-white, thin-bedded; black mineral inclusions are weathered to brown spots ---

22. Mudstone, dark-grayish-purple (violet) ----------

21. Sandstone, bluish-gray, very fine grained, hard and compact; contains mudstone beds interbedded in the middle part; some of the mudstone layers weather to yellow --

20. Siltstone and mudstone, dark-grayish-purple -----

19. Sandstone, grayish-yellow-pink; weathers yellowish gray, banded with white streaks; very fine grained, thin bedded; resistant black minerals stand upright on the weathered surfaces -------

18. Mudstone, dark-grayish-purple (violet); weathers to yellow --

17. Sandstone, very light gray, very fine grained, thick-bedded; contains reddish-brown concretion; one 18-inch-thick bed of medium-grained sandstone is slightly micaceous, silty ---------

16. Mudstone, dark-brownish-red, friable, silty ------

15. Sandstone, grayish-white, mottled with black minerals (resistant to weathering), very fine grained; middle part is hardest; upper is almost siltstone; lower part is medium bedded --.---.--

14. Mudstone, dark-grayish-purple (violet); with siltstone interbedded

13. Sandstone, grayish-orange-pink; weathers grayish pink; medium grained, silty; black minerals

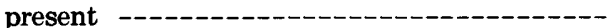

12. Siltstone, dark-grayish-purple (violet); yellowishblue weathered surface; shaly -

11. Siltstone, pinkish-white, medium- to thick-bedded;

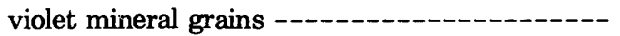

10. Mudstone, dark-grayish-purple (violet), friable ----

9. Mudstone, grayish-white; weathers to yellowish gray; silty --.---_-_-

8. Mudstone, dark-grayish-purple (violet), silty -..--

7. Sandstone, bluish-gray, very fine grained; contains black minerals, medium to thin.bedded, hard -_-

6. Mudstone, dark-blue; harder bands of siltstone of the same color interbedded; mudstone is silty ---

5. Sandstone, bluish-gray; weathers to yellowish pink; very fine grained, medium to thin bedded, upper part contains a layer of mudstone; hard and compact - 
4. Mudstone, dark-blue, silty

3. Sandstone, very light gray, upper part very thick bedded, lower part thick bedded with usual black minerals, abundant but very fine grained; upper part weathers to yellow and lower part weathers to bluish gray, hard and compact -----

2. Mudstone, bluish-gray, silty, friable -----------

1. Sandstone, very light gray, fine-grained; contains grayish-green shale bands; noncemented -Total thickness of Datta Formation

Triassic(?):

Kingriali Dolomite:

Dolomite, gray, thick-bedded

Section of Shinawari and Datta Formations measured in Punnoo Nala (lat $32^{\circ} 58^{\prime} N$., long $71^{\circ} 13^{\prime}$ E.), Surghar Range

Jurassic:

Samana Suk Limestone:

44. Siltstone, light-reddish-gray to dusky-yellow; contains pale-yellowish-brown, thin-bedded limestone, increasingly abundant and thicker bedded towards top, and thin beds of fine-

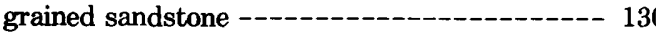

Shinawari Formation:

43. Claystone, blackish-red, in beds $4 \mathrm{ft}$ thick, interbedded with medium-gray siltstone in beds 6 in. thick

42. Sandstone, white, irregularly mottled dark red and orange, very fine grained, medium-bedded, irregularly bedded

41. Claystone, dark-reddish-brown, very thin bedded to platy; weathers into minute blocks ----------

40. Limestone, dusky-yellow, very fine grained, sandy ------------

39. Limestone, medium-dark-gray, dense, unfossiliferous; in thin beds to $8 \mathrm{in}$. thick, interbedded with grayish-brown and grayish-red shale

Total thickness of Shinawari Formation

$-\frac{40}{167 \quad 0}$

Datta Formation:

38. Sandstone, white, very thick bedded, very fine grained, silty, friable -...-_..- 65

37. Claystone, red, hard, blocky - -

36. Siltstone, blackish-red, mottled with small lightgray spots, grades into overlying unit -

35. Sandstone and siltstone interbedded; sandstone medium gray, mottled with reddish-brown spots, very fine grained, medium to thick bedded, irregularly and unevenly bedded, lumpy structure; interbedded siltstone and red shale in medium and thick beds --_-_-_-_-_-_-----

34. Siltstone, light-yellowish-gray, minutely laminated and marbled with dusky-red bands -------

33. Sandstone, light-gray, coarse-grained, angulargrained, very thick bedded; contains scattered quartz pebbles joints; contains beds of light-gray, fine- to medium-grained sandstone --.--_-_-_-_-----

31. Siltstone, as above, but without sandstone --.----- 10
Thickness

18

$12 \quad 9$

39

$\begin{array}{ll}10 & 9 \\ 59 & 9\end{array}$
30. Sandstone, light-gray, fine- to medium-grained,

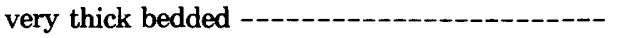

29. Sandstone, coarse-grained, pebbly; pebbles $1 / 16$ in. subrounded --_-

28. Sandstone, light-gray to white, medium-grained; in a single bed

27. Claystone, black; weathers yellowish brown; platy, coaly; in beds $3 \mathrm{ft}$ thick interbedded with white, very fine grained sandstone in 3-foot beds -----

26. Claystone, as above, but without sandstone --.---

25. Siltstone, dusky-red; weathers variegated dark gray and orange; in a single bed -...-........

24. Claystone, black; weathers yellowish brown; platy, coaly --_--_-

23. Sandstone, white; weathers light yellowish gray; very thick bedded, weakly laminated -..------

22. Siltstone, black, coaly, fissile ---

21. Sandstone, white; weathers light yellowish gray; very fine grained, very thick bedded, crossbedded red in thin irregular laminae; thick bedded, sandy, with clayey laminae; contains several thin coaly shale beds -........--

19. Claystone, dark-gray; weathers reddish black; coaly, pyritiferous; interbedded with siltstone and fine-grained sandstone in thin beds -------

18. Sandstone, white; contains abundant reddishblack ferruginous spheroids $1 / 4 \mathrm{in}$. in diameter; very fine grained, medium bedded, silty ----.--

17. Sandstone, white, thinly laminated with mediumdark laminae; crossbeds inclined mostly north erly; fine grained, angular grained -..---.----- 38

16. Claystone, medium-dark-gray, silty ---------

15. Sandstone, yellowish-gray; weathers grayish orange; fine grained, thin bedded, interbedded with thin beds of shale --_-_-_-_-_-_-_--

14. Siltstone, dusky-red, earthy, lumpy; top contains small pebbles of ironstone and clay --.------

13. Sandstone, as above -.....-.

12. Sandstone, yellowish-gray, thick-bedded, crossbedded; contains shale in beds 3 in. to $11 / 2 \mathrm{ft}$ thick; friable -

11. Claystone, medium-dark-gray, silty ------------

10. Sandstone, yellowish-gray; weathers grayish orange; fine grained, very thick bedded; contains two 1-foot claystone beds --_--_--------

9. Shale, brownish-gray, blocky, irregularly platy, slightly micaceous -

8. Sandstone, yellowish-gray; weathers grayish orange; very thick bedded, fine grained, subangular to subrounded; contains widely scattered

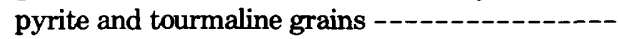

7. Claystone, medium-dark-gray, silty ------------

6. Sandstone, medium-gray, thick-bedded, very fine grained

5. Siltstone, very dusky red; contains vertical dykes of very fine grained sandsdtone $1 \mathrm{in.} \mathrm{thick} \mathrm{--.---}$

4. Sandstone, as above --_-

3. Siltstone, medium-gray, spotted grayish red, mottled with yellowish brown and red, medium bedded above, massive below --_--_-_---

2. Sandstone, light-gray; weathers reddish gray; thick bedded, fine grained; contains thin beds of gray claystone --_-_-_-_-_-_-_-_-_--
Thickness

Ft. In. 


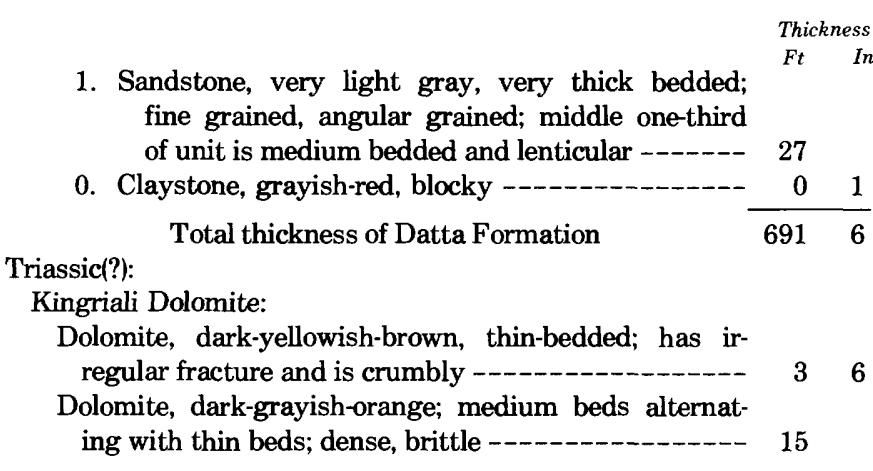

\section{SAMANA SUK LIMESTONE}

The Samana Suk Limestone, named by Davies (1930, p. 3) for rocks in the Samana Range near Hangu in the Kohat Disrict (fig. 2), was found by Meissner and others $(1974$, p. D9) to be essentially equivalent to the Baroch limestone of Gee (1945, table 1). The name Samana Suk is used because of precedence, in accordance with recommendations of the Stratigraphic Committee of Pakistan (written commun., 1968).

The Samana Suk is very well exposed on the flanks of an anticline cut by Baroch Nala (lat $32^{\circ} 56^{\prime} \mathrm{N}$., long $71^{\circ} 08^{\prime}$ E.), here proposed as a reference section of the formation in the Surghar Range. In this exposure the Samana Suk is $714 \mathrm{ft}$ thick. It consists mostly of hard, yellowish-gray, medium- to thick-bedded, finely crystalline to dense limestone. Thin layers of fine-grained sandstone are present throughout the Samana Suk, which is a ridge former.

The lower contact is in a gradation zone $50 \mathrm{ft}$ locally; downward, it consists of increasingly thick and prominent beds of yellowish-gray clay shale transitional to the lithology of the Shinawari Formation. The upper contact is sharp. The top surface of the Samana Suk is marked by small cavities and pits thought to have been formed by submarine solution of the limestone prior to deposition of the overlying Chichali Formation.

The thickness of Samana Suk southward of Baroch Nala is more than $714 \mathrm{ft}$ and northward decreases to an estimated $400 \mathrm{ft}$.

The Samana Suk is exposed in the south end of the Marwat Range, along the Khisor and Shinghar Ranges. It extends along the western Salt Range to Nammal Gorge, where it is beveled along the unconformity beneath the rocks of Tertiary age. The age of Samana Suk was determined as Late Jurassic (late Callovian) on the basis of a cephalopod fauna described by Spath (1939, p. 121). However, Fatmi (1972, p. 316) considers Samana Suk to be early to middle Callovian (Middle Jurassic) on the basis of middle Callovian ammonites that he describes from richly fossiliferous sections in the Datta, Poonnoo, Landa, Mallakhel, and Makarwal areas. A detailed description of the reference section follows:
Reference section of Samana Suk Limestone measured in Baroch Nala by S. Akhtar Imam

$$
\begin{aligned}
& \text { Thickness } \\
& \text { Ft In. }
\end{aligned}
$$

Cretaceous:

Chichali Formation:

50. Claystone, light-gray, platy; contains abundant foraminifera --

Jurassic:

Samana Suk Limestone:

49. Limestone, pale-yellowish-brown, in beds up to $3 \mathrm{ft}$ thick ---

48. Coaly, claystone, dark-brown, irregularly bedded -- $\begin{array}{rrr}1 & 6\end{array}$

47. Limestone, light-red, very fossiliferous --_-.-- $\quad \begin{array}{lll}0 & 3\end{array}$

46. Limestone, light-bluish-gray -_-_-_ $\quad 2 \quad 9$

45. Shale, reddish-brown -_- $0 \begin{array}{lll}9 & 0\end{array}$

44. Limestone, light-gray, sandy -..... 006

43. Limestone, light-gray, sandy, interbedded with claystone and sandstone --_-- 49

42. Limestone, light-yellowish-gray; lower part medium bedded, upper part thick bedded -.-_-_-- 60

41. Limestone, light-gray, friable, rich in fossils -..-- 16

40. Limestone, light-gray, friable, unfossiliferous ----- $2 \quad 6$

39. Limestone, pinkish-brown; lower part thin bedded and brittle -

38. Limestone, pale-yellowish-brown, thick-bedded, dolomitic, hard --

37. Limestone, as above, but very thick bedded ------

36. Sandstone, light-yellowish-gray, calcareous; contains bed of clay in middle of unit -...-.-.---

35. Shale, interbedded with sandy limestone --------

34. Limestone, dark-bluish-gray; weathers reddish gray --

33. Limestone, yellowish-brown, medium-bedded ----

32. Conglomerate, brownish-gray -_-

31. Sandstone, calcareous --

30. Limestone, sandy --

29. Shale, light-gray -

28. Conglomerate, lenticular-----

27. Limestone, thin- to medium-bedded; lower part silty, upper portion coarse grained, jointed and fractured -.-...--

26. Conglomerate, rich in fossils; consists of shell fragments and limestone pebbles cemented to gether in arenaceous matrix --.--_-_-

25. Limestone, yellowish-pink; upper part has thin bed of conglomerate; middle part has abundant

fossils and calcite-filled cavities -
24. Limestone, light-yellowish-gray, with bluish-gray interior, medium-bedded; contains few thin beds of claystone; sandy -

23. Limestone, bluish-gray, hard --_-_-_-_-_- 29

22. Claystone, bluish-gray -_-_- 116

21. Limestone, light-yellowish-brown, bluish within, dense, finely crystalline --

20. Limestone, as above, but very fossiliferous, interbedded with shale --

19. Limestone, light-yellowish-brown, hard -...---.-

18. Limestone, light-yellowish-brown, marly --------

17. Limestone, light-yellowish-brown; weathers .yellow; thick bedded, hard, dense --_-

16. Limestone, medium-gray, thick-bedded, interbedded with shale --_-.--

15. Limestone, medium-gray, thick-bedded; contains carbonaceous shale -

14. Laterite -..-

$\begin{array}{rr}8 & 10 \\ 5 & 6 \\ 2 & \\ 7 & \\ 86 & 10 \\ 9 & 11 \\ 21 & 2 \\ 1 & \end{array}$

$\begin{array}{ll}8 & 10\end{array}$

6

10

11

2 


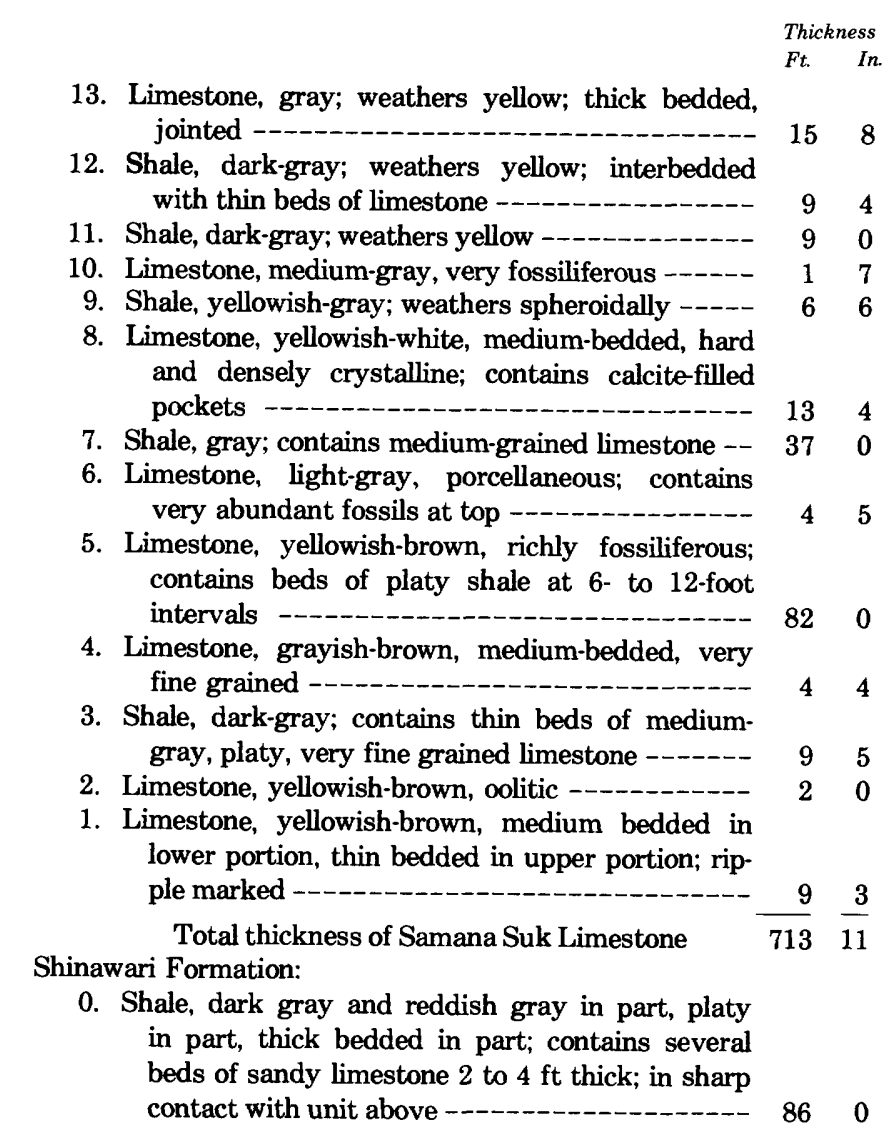

CRETACEOUS AND CRETACEOUS(?) SYSTEM

CHICHALI FORMATION

Chicali Formation is the name used by Danilchik (1961, p. D-228) to replace the descriptive name Belemnite beds, so called because of the prevalence of belemnites. The Chichali was named after Chichali Nala, in the Surghar Range, here designated as the type locality (lat $33^{\circ} 00^{\prime}$ N., long $71^{\circ} 25^{\prime} \mathrm{E}$.).

Throughout its outcrop extent in the western Salt Range, Surghar Range, and the southern end of Marwat Range, the Chichali consists predominantly of darkgreenish-gray glauconitic sandstone. The lower part is gray calcareous claystone about $50 \mathrm{ft}$ thick. The middle part is composed almost entirely of sand-sized glauconite grains that form a rock termed "greensand." Upward, the content of glauconite decreases. The glauconitic sandstone and greensand are well cemented by calcium carbonate, although on outcrops both the greensand and glauconitic sandstone are friable or loosely coherent because of weathering. Beneath the weathered surface the rock is firm and forms steep cliffs.

An iron-rich, glauconitic stratum, approximately $10 \mathrm{ft}$ thick in Chichali Pass, contains increasingly abundant chamosite and hematite as it is traced eastward toward the hills north of Kalabagh; this stratum diminishes farther east where the easternmost outcrops of the formation are part of a limonitic laterite layer along the unconformity beneath rocks of Tertiary age. The stratum is informally referred to as the "Kalabagh ironformation." Near the middle of the formation a stratum more than $20 \mathrm{ft}$ thick is relatively rich in iron and is comparable in composition to the "iron-formation" at Chichali Pass (fig. 2). Within this stratum and below, several beds, measuring as much as $11 / 2 \mathrm{ft}$ in thickness, consist predominantly of belemnite guards and a few well preserved coiled ammonite shells.

The uppermost part of the Chichali Formation, which contains scattered specimens of Gryphea, grades into the Lumshiwal Formation. The grain size of the glauconitic sandstone of the Chichali decreases upward, and the upper contact is at the base of the relatively coarser grained and lighter colored rocks of the Lumshiwal. The transition from Chichali to Lumshiwal lithology is very gradual, and because the contact zone is mostly along steep, inaccessible slopes, the upper contact was mapped only approximately.

The Sembar Formation, named by Williams (1959, p. 8), equals the Belemnite beds of Oldham $(1892$, p. 19) in Baluchistan and is probably equivalent in age to the Chichali. It is a dark-colored unit composed of black silty shale, nodular black siltstone, and dark limestone; locally, it is rich in glauconite, clearly indicating relation to the Chichali.

The age of the Chichali, based on cephalopods from Chichali Pass described by Spath $(1939$, p. 117), is considered to be Early Cretaceous. The fauna and age of the Chichali Formation have been discussed in detail by Fatmi $(1972$, p. $318-320$ ), who concludes that the Jurassic-Cretaceous boundary is in the upper part of its lower member. Fatmi divided the Chichali into three members. The lower silty and sandy shale member ranges from 70 to $110 \mathrm{ft}$ in thickness and contain ammonites and belemnites of late Oxfordian, early Kimmeridgian, early Tithonian (Late Jurassic), and Cretaceous age. The upper 2-3 ft contain Subthurmannia, and this part is considered transitional from Jurassic to Cretaceous. The middle member is a massive glauconitic sandstone unit ranging in thickness from 25 to $45 \mathrm{ft}$ and containing Berriasian and Valanginian ammonites. The upper member, described by Fatmi $(1972$, p. 319$)$ as sandy shale and glauconitic sandstone, does not contain ammonites, but Gryphaea and the belemnite Hibolithes are present 3 to $5 \mathrm{ft}$ below the upper contact. From these and other data, Fatmi assigns an age range from late Oxfordian to late Valanginian.

The Chicali Formation is approximately $200 \mathrm{ft}$ thick throughout most of the mapped area. Where measured 
in Baroch Nala, the Chichali is $233 \mathrm{ft}$ thick. Its type section, measured $227 \mathrm{ft}$ thick in Chichali Pass, is described below:

Type section of the Chichali Formation measured in Chichali Nala Thickness

Cretaceous:

Lumshiwal Formation:

13. Sandstone, light-gray, massive, fine to medium grained in upper part; contains plant fragments; very fine grained to silty, ferruginous, glauconitic; micaceous in lower part - -

Cretaceous:

Chichali Formation:

12. Greensand, dark-yellowish-brown, streaks yellowish-gray, coarse-grained; contains scattered ferruginous concretions --_-_-_- 10

11. Iron-formation, moderate-brown, streaks yellowishbrown, texture finely oolitic; contains abundant ammonites throughout, pelecypods in upper part --------------_---_-

10. Greensand, grayish-black, mottled yellowish-brown, streaks yellowish-gray; weathers spheroidally -- 9

9. Sandstone, medium-dark-gray, very fine grained, rich in glauconite; contains scattered pelecypods and plant fragments --_-_-_-_-_-_- 31

8. Greensand, yellowish-brown, fine-grained; contains very abundant belemnites and coiled ammonites; resistant to weathering --_-_-_-_-_-- 28

7. Greensand, grayish-black, medium-grained, friable; contains abundant cephalopods and scattered reptile bones --_-_-_-_-_-_-_- 25

6. Greensand, yellowish-brown, fine-grained, silty; contains swarms of belemnites and few molluscs 31

5. Siltstone, dark-yellowish-brown, very rich in glauconite; contains very abundant belemnites and small coiled ammonites --_--_-_-_-_-_--- 27

4. Siltstone, yellowish-gray, slightly glauconitic; contains scattered belemnites -_-

3. Covered interval underlain mostly by light-brownish-gray clay shale with very abundant belemnites of various kinds in upper part --_-_-_-- 53

Jurassic:

Total thickness of Chichali Formation

\begin{tabular}{rr}
53 & 6 \\
\hline 227 & 6
\end{tabular}

Samana Suk Limestone:

2. Limestone, light-brown, silty, medium- to thickbedded; top surface pitted spheroidally -....- 10

1. Limestone, light-yellowish-gray, mediumbedded --_-

\section{LUMSHIWAL FORMATION}

The Lumshiwal sandstone was named by Gee (1945, table 1), presumably after Lumshiwal Nala (lat $32^{\circ} 51^{\prime}$ N., long $71^{\circ} 09^{\prime} \mathrm{E}$.) in the Makarwal coal field, and is presently referred to as the Lumshiwal Formation (Fatmi, 1973, p. 34). The Lumshiwal corresponds to Wynne's $(1880$, p. 47) bed No. 9 of the section described in Chichali Pass.

The Lumshiwal Formation in the Makarwal area is defined as the sandstone that underlies the coal bed or its lateritic underclay and overlies the Chichali Formation. The lower contact with the Chichali is at the top of a transition zone of silty glauconitic sandstone. In the western Surghar Range the lower contact with the Chichali is at the top of a transition zone of silty glauconitic sandstone. In the western Surghar Range the lower contact is arbitrarily located, but in the eastern part the contact is sharp.

The Lumshiwal was deposited under terrestrial conditions. It consists mostly of light-gray, locally iron stained, medium- and coarse-grained thick-bedded sandstone containing beds of coaly shale and coal in the upper part. The subrounded grains are coarsest in its upper part, and pebbly bands are found locally near the top. The sandstone, commonly pyritic, decomposes to gypsiferous sandstone, which forms the white outcrops clearly visible from a distance in the Malla Khel area (pl. 1).

The lower part of the Lumshiwal locally consists of thick beds of carbonaceous and ferruginous silty sandstone that grade downward into the glauconitic siltstone and sandstone of the underlying Chichali. At 4-to 5-foot intervals, these beds of yellowish-brown ferruginous siltstone give its lower part a distinctive banded appearance. These lower, banded beds extend from Makarwal to Chichali Pass. Beyond Chichali Pass, these beds are absent, and the basal contact of the Lumshiwal is a well-defined surface marked by a lateritic and locally bauxitic deposit developed on a surface formed by erosion; therefore, it seems probable that the transition beds in the Makarwal area may have a wide age range.

Thin beds of carbonaceous shale and at least one bed of coal are found in the upper part of the Lumshiwal. The coal bed, well exposed along the trail leading to the Charles mine (pl. 2), is generally $25 \mathrm{ft}$ below the main Makarwal coal stratum. Throughout the coal field this bed is about $1 \mathrm{ft}$ thick and ranges in composition from predominantly coaly shale containing coal laminae to a single bed of bright coal.

The Lumshiwal Formation is $285 \mathrm{ft}$ thick, measured on the south side of Miranwal Nala gorge along the foot path leading from the nala to the old and new Miranwal mine (pl. 2). Elsewhere, in outcrops the Lumshiwal is estimated to be more than $350 \mathrm{ft}$ thick (see pl. 2, cross

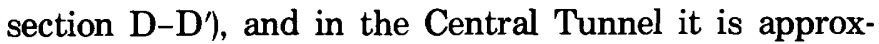
imately $500 \mathrm{ft}$ thick. In Baroch Nala (pl. 1) the Lumshiwal is $389 \mathrm{ft}$ thick, but northeast of the mapped area, in Chichali Pass (fig. 2), it is only $130 \mathrm{ft}$ thick. The Lumshiwal is very thin or absent in the western Salt Range. It may be present in the southern end of the Marwat Range; if so, it might correspond to beds No. 3 and No. 1 of Wynne $(1880$, p. 81,84$)$, which range from 70 to more than $130 \mathrm{ft}$ thick. 
The age of the Lumshiwal Formation was considered by Wynne 1880 , p. 47) and Gee (1938, table 1) to be Cretaceous. Spath (1939, p. 120) identified fossils of late Aptian age that were collected from a bed $650 \mathrm{ft}$ above the Samana Suk Limestone in the Marwat Range, near Shaikh Budin. This suggests that the post-Chichali rocks containing Cretaceous fossils exceed a thickness of $600 \mathrm{ft}$ in the Marwat Range. Unfortunately, the rocks are poorly described, and correlation cannot be made conclusively without field investigations in the area.

Fatmi (1972, p. 323) describes fossils including Gryphaea and Hibolithes in the basal 5 to $10 \mathrm{ft}$ of the formation in Baroch Nala outcrops; he states that "the formation's transitional contact with the underlying Neocomian beds and lithologic similarity with the Kohat sections (where the formation overlies known Early Cretaceous ammonite-bearing rocks of the Chichali Formation) suggest an Aptian(?) to mid-Albian age." In the Trans-Indus Mountains the formation apparently disconformably underlies, but is lithologically gradational with, a fossiliferous formation known to be of Paleocene age.

Type section of the Lumshiwal Formation measured in Miranwal Nala (lat $32^{\circ} 52^{\prime} N$., long $71^{\circ} 09^{\prime}$ E.) along the footpath leading from the Nala to the Miranwal mine

Paleocene:

Hangu Formation:

12. Coal (Makarwal main coal bed) --_-_-_-_-_-- 2+

11. Siltstone, yellowish-brown, irregularly thin bedded, sandy, very rich in iron --------- 11

Cretaceous:

Lumshiwal Formation:

10. Sandstone, white, massive-textured, very fine grained, friable - -

9. Siltstone, light-olive-gray, thin-bedded to irregularly platy, carbonaceous, sandy in part --_--- 26

8. Sandstone, medium-gray, thick-bedded, mediumgrained, subrounded, well-sorted; contains very abundant coalified plant fragments randomly scattered -...-- 7

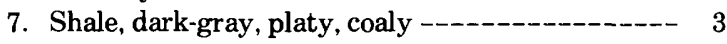

6. Sandstone, yellowish-gray; contains ferruginous bands closely spaced; medium grained, but gritty in top 1 foot; carbonaceous --..--..- 6

5. Sandstone, medium-dark-gray, platy, laminated with coaly bands irregularly distributed within unit; very fine grained, silty -..-.-.--

4. Sandstone, light-gray, very thick bedded, massive-textured, very coarse grained, subrounded concretionary in upper part --_-_.-- 105

3. Sandstone, light-gray, massive-textured, finegrained --_- 3

2. Sandstone, as above, but coarse grained and containing scattered pebbles ---_-_-_----- 2

1. Siltstone, medium-gray, thick-bedded; contains thin beds of ferruginous yellowish-brown sandstone in regular intervals of $5 \mathrm{ft}$; in gradational contact with underlying formation -----_---- 103

Total thickness of Lumshiwal Formation

\section{TERTIARY SYSTEM}

HANGU FORMATION

The name Hangu Formation supplants "Dhak Pass beds" of Davies and Pinfold (1937, p. 4) according to a decision by the Stratigraphic Committee of Pakistan (Fatmi, 1973, p. 39). Hangu was apparently chosen because of antecedence (Cheema, Raza, and Ahmad in Shah, 1977, p. 64).

Generally, the lower part of the Hangu resembles the underlying Lumshiwal Formation. The lower contact of the Hangu in this area is at the base of the Makarwal coal bed. Where the coal is absent, the contact is on a thin bed of lateritic clay that is believed to correspond to a lateritic clay that locally underlies the Makarwal in the southern part of the coal field. This lateritic clay may correspond in age and development to the bed of laterite that forms the base of the Hangu at its reference section at Dhak Pass.

Locally, near the middle part of the Hangu, a thin coal bed is as much as $2 \mathrm{ft}$ thick; it is referred to as the "upper coal bed." Its upper part is limy sandstone, claystone, and marl containing marine molluscan fossils of Paleocene age, but it is interbedded with carbonaceous siltstone beds similar to beds in its lower part. These rocks are therefore transitional in lithology from rocks apparently wholly of terrestrial origin below, to rocks wholly of marine origin above. A section of the Hangu measured in Lumshiwal Nala (lat $32^{\circ} 51^{\prime} \mathrm{N}$., long $71^{\circ} 09^{\prime} \mathrm{E}$.), along the cliff south of Zaroba village, is described below. The outcrop here is black because of iron oxide stain and coal dust. The upper contact of the Hangu is at a sharp lithologic break from carbonaceous or coaly shale and locally sandy marl, to the nodular limestone of the overlying Lockhart Limestone.

The thickness of the Hangu Formation ranges from $142 \mathrm{ft}$ in the southern part of the Makarwal coal field to $97 \mathrm{ft}$ in the northern part. Within the coal field, it appears to vary widely in thickness; the variation may be due to inclusion of the basal beds of the overlying Lockhart or the inclusion of upper beds from the underlying Lumshiwal. Therefore, the variations in thickness may not be real.

The Makarwal coal bed ranges from less than $1 \mathrm{ft}$ to as much as $3 \mathrm{ft}$ in thickness along exposures and as much as $10 \mathrm{ft}$ in the Makarwal coal mines. The outcrop is commonly no more than a narrow zone of carbonaceous shale or shaly sandstone, which is the result of deep weathering of the coal bed.

The age of the Hangu Formation is Paleocene accordto Krishnan (1960, p. 494). 
Section of the Hangu Formation measured in Lumshiwal Nala (lat $32^{\circ} 51^{\prime}$ N., long $71^{\circ} 09^{\prime}$ E.), along the cliff south of Zaroba village

Paleocene: Thickness

Lockhart Limestone:

21. Limestone, dusky-yellowish-brown, nodular------200+ Hangu Formation:

20. Siltstone, dark-brownish-gray, irregular platy, carbonaceous ------

19. Limestone, medium-gray, silty, marly in top 2 in. grading into overlying unit - -

18. Claystone, dark-brownish-gray, irregularly platy to massive-textured; slightly silty; contains very abundant molluscan fossils --_-_-_----

17. Sandstone, light-yellowish-gray, calcareous in upper half, carbonaceous with coaly material increasingly abundant downward in lower half --

16. Siltstone, pinkish-gray to yellowish-brown (decidedly dark, forming the brown band visible in distant outcrops), platy, containing closely spaced laminae of carbonaceous siltstone ------

15. Siltstone, dark-brownish-gray, carbonaceous -----

14. Sandstone, light-yellowish-gray, very thick bedded, very fine grained, calcareous near top; contains scattered gastropod fossils --_------ 18

13. Sandstone, light-yellowish-gray, very thick bedded, very fine grained; contains abundant carbonaceous laminae and irregular very thin stringers of coaly matter -

12. Covered interval, probably gray marl --_--_--- $3+$

11. Limestone, medium-dark-gray, very silty, marly at top, black and carbonaceous in bottom $2 \mathrm{ft}$ but containing scattered marine fossils --------- 10

10. Siltstone, brownish-black, fissile ---_-_-_-_--- 4

9. Sandstone, dark-brownish-gray, very thick bedded, very fine grained, silty; contains very abundant irregular laminae of carbonaceous siltstone ----

8. Sandstone, yellowish-brown, thick-bedded, very fine grained, very well sorted, locally ferrugi-

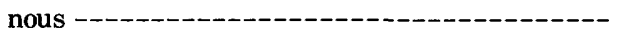

7. Sandstone, dark-brownish-gray, platy, interbedded with carbonaceous siltstone -

6. Sandstone, dark-gray, very thick bedded, very fine grained; contains very abundant carbonaceous siltstone laminae; light yellowish gray in weathered portions -

5. Shale, black, platy, carbonaceous --_--------- 4

4. Sandstone, light-gray, pebbly and gritty -------- 5

3. Shale, coaly -

2. Coal, Makarwal main coal bed -_._-_._-_._-_-_

1. Claystone, red, sandy --_- 9 Total thickness of Hangu Formation

$150 \quad 0$

Cretaceous:

Lumshiwal Formation:

0. Claystone, medium-dark-gray, blocky, massivetextured -.-_-_-_-_- 3

00. Sandstone, medium-gray, very thick bedded,

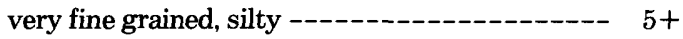

LOCKHART LIMESTONE

The name Lockhart Limestone was applied by Davies $(1930$, p. 10) to rocks exposed near Fort Lockhart in the
Kohat-Hangu area (fig. 1). Meissner and others (1974) correlated these rocks with those named by Gee (in Fermor, 1935 , p. 67) as the Khairabad limestones in the western Salt Range. Because of precedence, the name Lockhart replaces the name Khairabad in accordance with the recommendations of the Stratigraphic Committee of Pakistan (Fatmi, 1973, p. 40). The Lockhard is incorrectly referred to locally as "Ranikot Limestone."

The Lockhart is a distinctive, yellowish-brown, nodular, massive limestone. It forms vertical cliffs readily distinguishable from the steep slopes of the underlying Hangu Formation, with which it is in sharp conformable contact. The upper contact is arbitrarily placed at the top of the limestone cliff, but there is a thin transitional zone; thin beds of limestone similar to the Lockhart are present in the lower part of the overlying Patala Shale.

The Lockhart Limestone is $200 \mathrm{ft}$ thick in the southern part of the Makarwal coal field and is $120 \mathrm{ft}$ thick in the northern part. It ranges from 120 to $200 \mathrm{ft}$ in thickness in the Surghar Range.

The age of the Lockhart Limestone is Paleocene according to Krishnan (1960, p. 494).

\section{PATALA SHALE}

Davies and Pinfold (1937, p. 7) named the Patala Shale after Patala Nala in the Salt Range, which is here considered to be its type locality (lat $32^{\circ} 38^{\prime} \mathrm{N}$., long $71^{\circ} 49^{\prime} \mathrm{E}$.).

The Stratigraphic Committee recommended the usage of "formation" rather than "shale" apparently because in the Salt Range the Patala, though dominantly shale, includes beds of limestone, sandstone, and coal. The Committee extended the Patala to include both the Tarkhobi shale and Tarkhobi limestone of Eames (1952) in the Kohat area, despite the correlation and inclusion of the Tarkhobi limestone with the underlying Lockhart Limestone by Meissner and others (1974). This inclusion also justifies the use of "formation" in the stratigraphic name in the Kohat area. In the Surghar Range, however, the Patala is dominantly shale, so the use of Patala Shale in this area is appropriate and desirable.

The Patala Shale is predominantly dark-olive-gray to dark-gray, fissile to platy, richly foraminiferal clay shale. Locally, near the base, it contains a varying abundance of thin beds of limestone similar in lithology to the underlying Lockhart Limestone; these beds constitute a transition between the underlying Lockhart and the shale above. In the Makarwal area these beds are more readily mapped with the Patala because they are generally covered by slope deposits of the Patala instead of the bold cliffs that characterize the Lockhart. A thin lenticular bed of limestone containing excellent molluscan fossils is present near the middle of the 
Patala. Thin beds, as much as $3 \mathrm{ft}$ thick, of light-gray to bluish-gray marl, are present near its top. Although the Patala contains coal beds in the eastern Salt Range, none is found in the Makarwal area. The Patala forms slopes, and scree derived from overlying formations normally covers it.'The lower and upper contacts are in thin zones that are lithologically transitional to the underlying and overlying formations.

The maximum thickness of the Patala Shale within the Makarwal coal field is estimated to be $500 \mathrm{ft}$; it apparently thins northward within the coal field to an estimated thickness of only $250 \mathrm{ft}$ west of Baroch Nala (fig. 6). The formation is 100 to $250 \mathrm{ft}$ thick in the western Salt Range but is 250 to $400 \mathrm{ft}$ thick in the western Surghar Range. It is not present in the Marwat and Khisor Ranges.

The age of the Patala Shale is Paleocene according to Haque (1956, pl. I).

NAMMAL MARL

The term Nammal Marl is here modified for usage in the Trans-Indus Mountains from Gee's designation (in Fermor, 1935, p. 67), which was originally "Nammal limestones and shales." The Nammal is here restricted to rocks predominantly of marl or light gray shale that comprise the lower half of the 400-foot thickness originally designated in the type section.

Davies and Pinfold (1937) mention that the Nammal

$* * *$ consists of limestones, marls and shales in varying proportions. Neither in lithology nor in the fossils is there any clear-cut distinction between the Nammal and Sakesar divisions of the Laki, ${ }^{2}$ but in the Nammal neighborhood and further northwest there is a considerable thickness of light-gray shale at the base of the Laki. In the Patala section the lowest $200 \mathrm{ft}$ is almost entirely composed of gray shale, and these are overlain by $200 \mathrm{ft}$ of alternating limestone and shale. These are here included in the Nammal division, but Messrs. Gee and Evans now think that it might be better to restrict the Nammal divisions to the lower $200 \mathrm{ft}$ and to the corresponding beds in the Nammal gorge.

The reason for including the upper half in their Nammal is not clear. The lower half constitutes an easily mappable unit in the western Salt Range and throughout its extent in the Surghar Range. The upper half, therefore, is here assigned to the overlying Sakesar Limestone, leaving the term "Nammal" restricted to the lower half. The descriptive term "marl" is used because the formation is predominantly a blue marlstone.

In the mapped area (pl. 1) the Nammal Marl consists of light-gray to light-bluish-gray marl containing marine fossils and thin irregular beds and nodules of white limestone. The marl is thought to grade laterally into white, massive, chalky limestone that resembles the basal beds of the overlying Sakesar, indicating that

\footnotetext{
${ }^{2}$ Obsolete name for the Sakesar Limestone and Nammal Marl.
}

the upper contact changes in stratigraphic position from place to place.

The Nammal characteristically underlies debriscovered slopes. Locally, it appears to be very thin or absent. In the southern part of the coal field, the Nammal is estimated to be $165 \mathrm{ft}$ thick, but in the northern part (pl. 1), it is indistinguishable from the overlying Sakesar and not mapped locally as a separate unit. Near the Punnoo mines in the northern part of the quadrangle (pl. 1) the Nammal is $56 \mathrm{ft}$ thick.

The Nammal Marl locally has a sharp contact with the Patala Shale, but in some areas in the western part of the Surghar Range the contact is within a transition zone less than $10 \mathrm{ft}$ thick. The Nammal ranges in age from Paleocene to early Eocene according to Haque (1956, p. 26).

SAKESAR LIMESTONE

The Sakesar Limestone (incorrectly referred to locally as "Laki" limestone) was named by Gee (in Fermor, 1935 , p. 61) for the village of Sakesar (fig. 2). The type section has not been described.

As used in the Surghar Range, the Sakesar Limestone includes the white, massive, fossiliferous, locally nodular limestone that conformably overlies the Nammal marl in sharp contact. The Sakesar forms the high escarpment that flanks the Surghar Range in the Makarwal area. Its lower part is massive- to thickbedded, cherty, dense limestone. The limestone of its middle part is locally marly or chalklike and thick bedded. Its upper part consists of thick beds of bluishgray marl interbedded with nodular limestone and nodular marl. Its topmost beds immediately west of Makarwal Kheji (pl. 1) are massive nodular limestones that resemble the Lockhart.

The thickest and most complete section of the Sakesar is in the southern part of the coal field, where it is estimated to be more than $1,800 \mathrm{ft}$ thick. Abrupt thinning to $650 \mathrm{ft}$, which takes place northwest of Makarwal Kheji, is apparently due to erosion of its upper beds in areas that were uplifted and bevelled prior to deposition of the overlying Mitha Khatak Formation. In the Salt Range the thickness of the Sakesar varies from 240 to $400 \mathrm{ft}$.

The Sakesar, as distinguished in the Surghar Range, probably includes rocks that can be correlated with formations that have been identified and described as units that overlie the Sakesar in the Salt Range and elsewhere (table 1). However, subdivision and correlation have not been attempted because the Sakesar crops out along inaccessible vertical cliffs of the Surghar escarpment, and subdivisions would not be mappable at usual map scales. 
The upper contact of the Sakesar is along an erosional, locally angular unconformity thought to have a wide stratigraphic range in the Surghar Range. The angular unconformity between the Sakesar and the overlying beds is readily apparent south of the coal field, southwest of the village of Mitha Khatak (pl. 1).

The Sakesar appears to thin eastward in the Surghar Range and southward in the Salt Range. Some of the thinning may be due to an unconformity within the Eocene, as suggested by Davies and Pinfold (1937, p. 12).

The age of the Sakesar Limestone is early Eocene (Haque, 1956, p. 26).

\section{MITHA KHATAK FORMATION}

The Mitha Khatak Formation is a newly designated rock unit that underlies the rocks of the Siwalik Group without discordance and unconformably overlies the Sakesar Limestone with very slight angular discordance in the western Surghar Range. The type locality of the Mitha Khatak is along the mouth of the gorge northeast of the village of Mitha Khatak (lat $32^{\circ} 48^{\prime} \mathrm{N}$., long $71^{\circ} 09^{\prime} \mathrm{E}$.). Above a basal conglomerate, thick beds of moderate-yellowish-brown, fine-grained, pebbly sandstone with rounded to subrounded grains are interbedded with very thick beds of moderate-reddish-brown, clayey siltstone that is increasingly abundant toward the top of the Mitha Khatak. The basal conglomerate ranges from 5 to $25 \mathrm{ft}$ in thickness. It is yellowish brown and consists predominantly of well-sorted cobbles, as much as 3 in. in diameter, and pebbles of limestone and, rarely, of chert derived from the underlying Sakesar. The matrix of the conglomerate and the overlying beds of sandstone is mostly yellowish brown, fine to coarse grained, and consists of rounded of rounded to subrounded polished quartz grains. Cement is calcareous.

The basal conglomerate includes cobbles derived from the underlying Sakesar and widely scattered pebbles and cobbles of quartzite and granite that resemble those in the Tobra Formation (formerly "Talchir Tillite") of Permian age. The nearest exposure of the Tobra Formation is $40 \mathrm{mi}$ to the south in the Khisor Range.

At least one bed of sandstone contains coarse mica, but most beds are not micaceous. The interbedded siltstone is moderate reddish brown, very thick bedded, sandy, clayey, and marly. One lens of light-brown, finely crystalline, sparsely fossiliferous limestone is present along the slope of the ridge west of Mitha Khatak.

A sequence of red siltstone beds $190 \mathrm{ft}$ thick overlies the topmost sandstone bed of the Mitha Khatak Formation. These beds are similar in lithology to beds of siltstone within the Mitha Khatak and constitute a transitional zone between the Mitha Khata and the overlying Chinji Formation of the Siwalik Group. These beds are not included in the Mitha Khatak because the rocks are also similar to the brick-red siltstone and claystone of the Chinji Formation. The uppermost horizon of the clean quartzose sand that characterizes the Mitha Khatak is the upper contact separating the Mitha Khatak from the medium-gray, angular-grained, graywacke-type sandstone of the overlying Siwalik Group.

The lower contact is sharp where the underlying Sakesar Limestone is massive; locally, where the Sakesar is nodular, the contact is indistinct. The thickness is $340 \mathrm{ft}$ at the village of Mitha Khatak (fig. 2), the type locality. Two measured sections of the Mitha Khatak are given below.

The age of the Mitha Khatak Formation is not known; the only fossil, an echinoid from a thin lens of limestone along the ridge southwest of the type section, was too weathered for specific identification. The Mitha Khatak may be equivalent to the "red claybeds" (table 1) of Eocene age that crop out in the western Salt Range near Daud Khel or the Bhadrar beds also of Eocene age, or they may be equivalent to part of the Murrees. Wynne $(1880$, p. 55) discussed the rocks in the vicinity of Mitha Khatak, stating that "this group of clays, sandstones, and conglomerates has greatly the appearance of those recognized as identical with part of the Sabathu Group [Eocene of Simla District, India] in other parts of the Upper Punjab, and, like it, presents $* * *$ perfect conformity of stratification with the underlying nummulitic limestone although containing fossiliferous nummulitic limestone pebbles derived from other localities."

The coarse clastic rocks, including granitic cobbles and pebbles, the rounding of sand grains, and the disconformably lower contact of the Mitha Khatak, indicate great uplift of large areal extent and possibly of prolonged duration. This kind of uplift is not reflected in any of the rocks of Eocene age in the adjacent areas and therefore is believed to be Oligocene or Miocene and related to the beginning of Himalayan orogenesis. ${ }^{3}$

The rocks overlying the Sakesar Limestone on the north side of Chichali Pass, although occupying the stratigraphic position of the Mitha Khatak Formation, are probably younger and may belong to the Chinji Formation. Their basal conglomerate contains pebbles and cobbles of poorly cemented sandstone thought to be from the Siwalik Group. However, the dark-brownishred claystone and siltstone cropping out along the south entrance of Chichali Pass may be part of the transitional beds that overlie the Mitha Khatak. The lateral discontinuity of the Mitha Khatak may be due to erosion prior to deposition of the Chinji Formation in the area.

\footnotetext{
${ }^{3}$ In accord with Hemphill and Kidwai (1974), the Mitha Khatak Formation may be ageequivalent to the Chitarwata Formaton of Miocene age that is extensively exposed along the Sulaiman Range.
} 
Type section of Mitha Khatak Formation measured at Mitha Khatak

Miocene:

Chinji(?) Formation:

18. Sandstone and silty claystone, alternating; lowermost bed is light olive gray, very thick bedded, coarse grained, subangular to angular, weakly cemented; contains abundant dark minerals and calcite grains. Claystone is pale reddish brown, slightly silty ---_---_------ $50+$

17. Covered interval, probably mostly moderate yellowish-brown siltstone --_------ 190

Miocene or Oligocene:

Mitha Khatak Formation:

16. Sandstone, light-yellowish-gray, fine-grained in upper half; lower half very coarse grained and contains abundant small limestone pebbles ----

15. Siltstone, moderate-reddish-brown, clayey; contains thin beds of moderate-yellowish-brown, very fine grained sandstone and light-gray siltstone --_---_-_- 85

14. Sandstone, light-yellowish-gray, irregularly bedded, massive-textured, very coarse grained, subrounded, well-sorted --_-_-_-_- 6

13. Siltstone, moderate-reddish-brown, clayey, sandy - 34

12. Sandstone, moderate-yellowish-brown, finegrained, increasingly silty towards the top; a single massive-textured bed

11. Sandstone, light-yellowish-brown, crossbedded, very coarse grained, rounded, limy; thickens abruptly --------

10. Sandstone, moderate-yellowish-brown, earthytextured, coarsegrained, rounded, rich in silt and clay; contains coarse flakes of biotite and scattered small clay pebbles --_-----_-------- 14

9. Sandstone, moderate-yellowish-brown, very thick bedded; very fine grained; contains sedimentary dikes, also widely scattered, rounded grit-sized pebbles

8. Sandstone, light-yellowish-gray, massive-textured; coarse grained, rounded to subrounded --------

7. Conglomerate, moderate-yellowish-brown; consists of limestone cobbles up to $3 \mathrm{in}$. in diameter and pebbles, well rounded, poorly sorted, in a matrix of medium-grained, subrounded quartz sand

6. Covered interval, but probably containing sandstone and conglomerate -

5. Sandstone, moderate-yellowish-brown, massivetextured, very fine grained, containing scattered cobbles

4. Sandstone, as above, but containing very abundant small clayey concretionally masses -------

3. Sandstone, moderate-yellowish-brown, finegrained, massive-textured, pebbly in middle of unit --_-_- 18

2. Sandstone, moderate-yellowish-brown, massivetextured, medium-grained, subrounded, quartzose sisting of limestone cobbles and pebbles, well rounded, poorly sorted, in a matrix of mediumgrained, subrounded quartzose sand ----------

Total thickness of Mitha Khatak Formation

Thickness
Ft In
Eocen

Unconformity

Sakesar Limestone:

not measured

Section of Mitha Khatak Formation measured in Baroch Nala

Pliocene:

Chinji Formation:

30. Sandstone, gray, medium-grained with abundant black minerals; grains are subangular to angular 3

29. Shale, grayish-green, concretionary ------------ 22

28. Shale, dirty-red and light-green; contains some thick beds of medium- to coarse-grained sandstone -...-

Miocene or Oligocene:

Mitha Khatak Formation:

27. Sandstone, grayish-green; lower part is gritty, upper part is medium grained; the lower part has white salt incrustation on the surface --.---_-- 15

26. Sandstone, lower part is gray and the upper part is grayish green; upper part is conglomeratic and the lower is coarse-grained sandstone with medium-grained groundmass; thick bedded ---- 5

25. Shale, dirty-red with grayish green in the middle portion; concretionary --.-------.-- 21

24. Sandstone, grayish-green, medium- to coarsegrained, concretionary, thick-bedded --------- 9

23. Shale, dirty-red; concretionary --_-_-_-_--- 11

22. Sandstone, grayish-green with few pinkish-red patches, medium-grained upper part grades to coarse-grained lower part; cliff forming; conglomeratic bed at base, diameter of pebbles ranges to 3 in. ---

21. Sandstone, grayish-green, very coarse grained (somewhat gritty); grains are angular to subrounded --_--_-

20. Shale, dirty-red, concretionary; uppermost is almost greensand, lowermost is pure shale; abundant sandy concretions in middle of unit -..---- 24

19. Conglomeratic sandstone, grayish-green, very coarse grained, round-grained; black grains abundant --_-

18. Conglomeratic sandstone, grayish-green, very coarse grained, round-grained; black grains

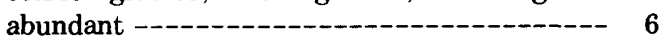

17. Shale, grayish-green, concretionary -..------

16. Shale, dirty-red with green patches, especially in the upper part; concretionary -------------- 20

15. Sandstone, grayish-green; weathers brown; medium to coarse grained; lower part is medium grained; some layers are very coarse grained, ranging to conglomeratic --_-_-_--- 28

14. Sandstone, brownish-green, medium-grained, at some places coarse grained; calcareous efflorescence forms crust on the surface; contains a shale bed in the upper part --..--

13. Shale, dirty-red, concretionary; coarse sand grains

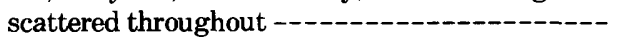

12. Sandstone, light-green; weathers to violet; very coarse grained to coarse grained, loose, poorly cemented; quartz grains are rounded to sub-

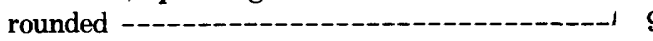

11. Conglomeratic sandstone, light-olive-gray, coarsegrained, upper 28 in. pure conglomeratic bed --- 14
Thickness

Ft. In.

22

56

5

5

5

20


10. Shale, dirty-red, concretionary with very coarse grained sand pebbles; grains are rounded to subrounded; upper part is green and harder than

9. Conglomeratic sandstone, light-olive-gray, very coarse grained to medium-grained, hard and well-cemented; some of the coarse grains are

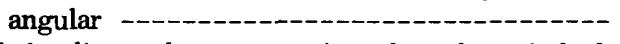

8. Shale, dirty-red; coarse grains of sand are imbedded or concretionary, hard -...--..-

7. Sandstone, green; weathers to bluish green; medium to coarse grained, thick bedded --.---.---

6. Sandstone, grayish-green; weathers to violet; coarse grained; contains conglomeratic lenses; upper part is medium bedded and less conglomeratic, but impersistent; hard and well cemented

5. Conglomeratic sandstone, grayish-green; very coarse grained; contains few pebbles of limestone; pebbles of sandstone are rounded and hard; thick bedded, irregular; upper part is comparatively soft -...-.......--

4. Conglomerate bed, white limestone boulders smaller in size than in unit 2; pebbles are nummulitic --------------------------

3. Conglomeratic sandstone, grayish-green; medium to coarse grained, very thick bedded; contains lenses of conglomeratic beds ---------

2. Conglomerate, white limestone boulders cemented with calcareous matrix; maximum diameter is 6 in.; boulders are rounded to subrounded, irregularly bedded and impersistent --.---.---

Eocene:

Total thickness of Mitha Khatak Formation

\begin{tabular}{rr}
7 & \\
\hline 289 & 1
\end{tabular}

Sakesar Limestone:

1. Limestone, white; very thick bedded, cliff forming, hard; highly fossiliferous -------_----- not measured

\section{TERTIARY AND QUATERNARY SYSTEMS}

SUB-HIMALAYAN SUPERGROUP (IN PART)

The "Sub-Himalayan System" of Medlicott (1964, p. 10) was formalized to Sub-Himalayan Supergroup by the Stratigraphic Commission of Pakistan (written commun., 1968) but restricted in the sense of Anderson's $(1927$, p. 673) "Nimadric System" to the "continental deposits of the region which, as a whole, exhibit a contrast with the dominantly marine succession below and were, together as the youngest unit, involved in the last major tectonic stage of the Himalayan orogeny."

The Sub-Himalayan Supergroup includes the Rawalpindi and Siwalik Groups. The Rawalpindi Group, ranging in age from early to late Miocene, consists of the Murree and Kamlial Formations. Neither formation is present in the Trans-Indus Mountains. The Siwalik Group ranges in age from Miocene to Pleistocene. The numerous formations comprising the Siwalik, though generally poorly fossiliferous, are well developed and very well exposed in the Trans-Indus Mountains.
Siwalik Group

Lewis $(1937$, p. 197) proposed a classification for the Siwalik Group following the principles of stratigraphic classification of Ashley and others (1933). His classification, generally accepted by the writers, has been modified to comply with the Stratigraphic Code of Pakistan. Modifications inlude applying the lithostratigraphic rank "group" instead of Lewis' chronostratigraphic rank "series."

The Chinji, Nagri, and Dhok Pathan Formations were first described by Pilgrim (1913, p. 40) as faunal zones. Pilgrim employed the lithostratigraphic classification "Lower, Middle, and Upper Siwaliks." Subsequent workers (Anderson, 1927; Cotter, 1933) applied the names in the sense of lithostratigraphic units but referred to them as "stages" that, in the usage of the time, combined the concepts of time and lithology. Lewis' classification restricts the Chinji, Nagri, and Dhok Pathan to the concept of lithostratigraphic units, which he refers to as formations. Lewis' subdivisions of the Siwalik, namely "Lower, Middle, and Upper Siwalik Groups," may be ranked as subgroups. However, the writers have not required these subdivisions.

The formations comprising the Siwalik Group in the Surghar and Shinghar Ranges include, in ascending order, the Chinji, Nagri, and Dhok Pathan Formations, which have a total thickness greater than $12,000 \mathrm{ft}$. These formations were named after the localities on the Potwar Plateau. In the Marwat and Bhittani Ranges, Morris (1938) named the rocks of the Siwalik Group, in ascending order: Karghocha, Marwat, Sheri Ghasha, and Malagan Formations; he found the Karghocha, Marwat, and Sheri Ghasha to be younger than, but comparable lithologically (homotaxial) to, the Chinji, Nagri, and Dhok Pathan of the Potwar Plateau.

Hemphill and Kidwai (1974) regard the names Karghocha, Marwat, and Sheri Ghasha to be synonyms of Chinji, Nagri, and Dhok Pathan. This follows the usage applied to homotaxial units that is recommended in Article 2, Remarks (a) of the code of Stratigraphic Nomenclature (American Commission, 1961, p. 649).

The age relations of the formations are shown diagrammatically in figure 4 . General descriptions of the units are given in the following paragraphs.

\section{Chinji Formation}

The Chinji was named by Pilgrim $(1913$, pl. 26) after the village of Chinji (lat $32^{\circ} 42^{\prime} \mathrm{N}$., long $72^{\circ} 22^{\prime} \mathrm{E}$.) on the Potwar Plateau (fig. 2). Lewis (1937, p. 200) designated the type locality of the Chinji to be immediately south of the village.

The Chinji consists predominantly of very thick beds of reddish-brown to reddish-gray sandstone. The 
lowermost unit of the Chinji consists largely of siltstone and silty claystone and contains subordinate but thick beds of sandstone. These sandstone beds are thick, medium gray, and medium grained, containing angular grains of calcite and feldspar, and are interbedded with pale-reddish-brown siltstone. The middle part of the Chinji is predominantly very thick bedded claystone and generally forms slopes or valleys; where exposed, it constitutes the most colorful part of the Siwalik Group. The uppermost $800 \mathrm{ft}$ of the Chinji form a lithologic transition zone with the dominantly sandstone rocks of the overlying Nagri Formation.

The Chinji Formation unconformably overlies the Sakesar Limestone and the Mitha Khatak Formation in the Surghar Range, and the "red claybeds" and the Kamlial Formation in the western Salt Range. The Chinji is not present in either the Khisor or Marwat Ranges.

The base of the Chinji is mapped at the base of the lowermost beds of gray, thick-bedded, angular-grained sandstone. This lowermost sandstone unit may be equivalent in age to the "Kamlial beds" of Cotter (1933, p. 109) in the Potwar Plateau. The thickness of the Chinji is estimated to range from 3,700 to $5,700 \mathrm{ft}$; it is more than $6,000 \mathrm{ft}$ thick in the Shinghar Range. The age of the Chinji Formation in the type locality is late Miocene according to Lewis (1937, p. 200).

$$
\text { Nagri Formation }
$$

Lewis (1937, p. 199) adopted Pilgrim's name for the faunal zone, Nagri, and referred to the rocks containing the fauna as a lithostratigraphic unit, the Nagri Formation. He designated Nagri village on the Potwar Plateau as its type locality. Gee's Nagri of the Trans-Indus Mountains has been correlated lithostratigraphically by Cotter (1933) and others with the Nagri of the Potwar Plateau. The name Nagri supplants the older term "Dangot sandstone" applied by Wynne $(1877$, p. 120) to the massive sandstone exposed on Dangot Hill (lat $32^{\circ} 59^{\prime}$ N., long $71^{\circ} 36^{\prime} \mathrm{E}$.) near Kalabagh, or Dungote of Waagen (1889, p. 17). Although the term Dangot (currently spelled Dhingot) has priority over the name Nagri in the Trans-Indus area (fig. 3), the Stratigraphic Commission of Pakistan (written commun., 1968) has accepted the latter because Nagri is a widely used and generally accepted stratigraphic term.

The Nagri Formation consists almost wholly of very thick sandstone beds. The sandstone is medium gray, very thick bedded, commonly crossbedded, medium grained, angular to subangular, micaceous, feldspar-rich, marly, silty, and in some beds, clayey. The formation contains a few thin lenticular pebble-conglomerate beds and widely scattered pebbles throughout. The pebbles are rounded and consist of chert, quartzite, milky quartz, granite, diorite, and, rarely, rhyolite. Crossbedding suggests a southwesterly direction of sediment transport.

In the Shinghar Range the Nagri is more than $6500 \mathrm{ft}$ thick and consists almost wholly of massive, gray, medium-grained sandstone. Its lower contact is transitional and may not be placed at the same stratigraphic position by different workers. For the purpose of this report, its base is arbitrarily placed on the top of a prominent bed of siltstone that is readily recognized and easily traced on aerial photographs. Its upper contact at the topmost arenaceous bed provides a sharp contact with the overlying Dhok Pathan Formation. The thickness of the Nagri is estimated to be between 6,350 and $6,500 \mathrm{ft}$.

The age of the fauna of the Nagri at the type locality is regarded by Pilgrim (1913, pl. 26) to be early Pontian, by W. D. Matthew (in Cotter, 1933, p. 114), as not earlier than Pontian, and by Lewis $(1937$, p. 199) as early Pliocene. Morris $(1938$, p. 393) correlated the "Marwat formation," which contains a fauna of Pleistocene age, with the Nagri on the basis of lithology and position in the stratigraphic succession (fig. 4). However, most of the Nagri of the Surghar Range is probably older than Morris' "Marwat formation." Therefore, the age of the Nagri Formation of the Surghar Range is within the interval ranging from early Pliocene through early Pleistocene.

\section{Dhok Pathan Formation}

The name Dhok Pathan, after the village by that name on the Potwar Plateau (lat $33^{\circ} 38^{\prime}$ N., long $72^{\circ} 21^{\prime}$ E.), was first applied by Pilgrim $(1913$, p. 40,277$)$ to beds regarded as a faunal zone. They were treated as a lithostratigraphic unit by Cotter (1933, p. 104) and later by Lewis (1937, p. 198), and this procedure is used here. The term Dhok Pathan was applied by Gee $(1945, \mathrm{pl} .1)$, in keeping with Wynne's classificaton of "Upper Siwalik" (not Pilgrim's "Upper Siwalik Group") for the uppermost formation of the Siwalik Group in the TransIndus Mountains. Gee's nomenclature is conditionally adopted in this paper, but his classification is modified.

The type locality of the Dhok Pathan Formation, as designated by Lewis, is along the Soan River at Dhok Pathan village, which also is the type section of Pilgrim's faunal zone. The rocks in the type locality consist of brown, red, and orange claystone and siltstone, interbedded with white sandstone in thick beds.

Only the lower part of the Dhok Pathan is exposed in the Makarwal quadrangle, underlying areas of low relief. This unit contains alternating layers of micaceous, thinly laminated clayey siltstone. The exposed beds of the uppermost part include conglomerate consisting of pebbles and cobbles of granite, gneiss, chert, 
and quartzite. These pebbly beds may indeed belong to or be equivalent in age to named units that are younger than the Dhok Pathan. However, the pebbly beds were not sufficiently exposed to permit recognition of the stratigraphic relationship to the underlying, typically pebble-free Dhok Pathan, and were not mapped separately. The exposed thickness of the Dhok Pathan exceeds $2,500 \mathrm{ft}$.

In the Shinghar Range, the formation consists of light-yellowish-brown siltstone in thick beds alternating with yellowish-brown, thinly laminated, finely micaceous, clayey siltstone. No basal conglomerate or discordance of any kind is noted except the sharp change of lithology from the massive sandstone of the underlying Nagri Formation to the siltstone of the Dhok Pathan. The Dhok Pathan is thought to be a homotaxial equivalent of the Sheri Ghasha Formation and, at least in part, of the Marwat Formation, which contains a Pleistocene fauna. The age of the Dhok Pathan Formation at the type locality is post-Pontian (middle Pliocene), according to Lewis (1937, p. 199).

Morris (1938, p. 415) recognized the difference of age between the same lithostratigraphic units in the TransIndus Mountains and Potwar Plateau; he concluded that the deposition of the Siwalik Group proceeded slowly from east to west (fig. 3). Thus, the environmental conditions that gave rise to one or another kind of sedimentary rock would also have moved from east to west. It is possible that the Dhok Pathan Formation of the Trans-Indus Mountains has a longer age range than its correlative in the Potwar Plateau.

\section{DEPOSITS OF QUATERNARY AGE}

Unconsolidated and poorly cemented products of rock weathering and erosion comprise the deposits of Quaternary age. These include alluvium, colluvium, aeolian deposits, and slump or landslide deposits. The slump deposits consist of clastic masses of locally derived boulders and soil transported in landslides. The deposits include alluvium in the beds of modern streams, fan alluvium, terrace deposits, and alluvial soil deposits of the plains.

In the Makarwal quadrangle, the alluvial deposits have been differentiated on the basis of age. The criterion for age differentiation is based on generally observable field relations-the older alluvial deposits belong to a completed cycle of deposition and are now being eroded, whereas the younger alluvial deposits are now accumulating. Thus, the terrace deposits are similar to modern alluvial deposits but underlie flat, gently inclined, raised surfaces and are now being dissected. They occur at widely differing altitudes; the large terrace west of Maidan (pl. 1) developed behind a mass of landslide debris. Other deposits overlie terraces that represent the old topography of valleys whose streams are now deeply incised.

The older alluvium also includes old alluvial fan deposits that crop out north of Makarwal Station; they are shown in (pl. 3). The rock of these outcrops consists of limestone boulders, cobbles, and sand firmly cemented with calcareous cement or travertine. The rocks dip west; if these are initial dips, it could be inferred that the outcrops represent remnants of a now buried west slope of a ridge eroded away long ago. It is also possible that the outcrops represent older alluvium that has been uplifted along young faults.

The younger alluvial boulder fans consist of limestone boulders and cobbles in a matrix of silty sand or gravel, except in the area east of Kurdi, where the matrix consists of dark clay. This clay was derived by weathering of the Patala Shale, which crops out in many places in the Kurdi area (pl. 1). The alluvial fan deposits appear to be very thick.

Talus deposits or colluvium (pl. 1) are differentiated from the alluvial fans only by the nature of their occurrence on steep slopes and the angular appearance of the locally derived bouldery constituents. The colluvial deposits are generally thin except where they overlie the Patala Shale. There the accumulation of angular blocks of Sakesar Limestone forms colluvial deposits that may exceed an estimated thickness of $50 \mathrm{ft}$ over wide areas north of Makarwal Kheji.

The soil and alluvium of the Bannu Plain and the southernmost part of the Indus Plain (fig. 2) consist of sandy silt and sand largely derived by weathering of the Siwalik rocks. In contrast, the soil and silt of the Indus Plain are loamy and marly. Wind-transported silt and fine sand probably constituted a major part of the soil and alluvium of the plains.

Stream alluvium, shown in plates 1 and 2, consists of sand and fine gravel in the beds of modern streams. Traced out onto the plains, the stream alluvium commonly becomes indistinguishable from the soil and alluvium of the plains.

Slump deposits consist of detached larger blocks that slid from the steep outcrop of formations to their resting places. the large slump blocks southwest of the Powerhouse (pl. 2) consist of rocks from the Lockhart Limestone and Hangu Formation; the blocks are thought to have slid southeastward from the area of the anticlinal axis in the present gorge of Miranwal Nala. These blocks lie diagonally across the outcrop belts of the Patala Shale and the Lockhart Limestone.

\section{STRUCTURE OF THE MAKARWAL COAL FIELD}

Two major episodes of mountain-making activity have been recognized in the Makarwal area. During 
these episodes the Makarwal coal bed and its enclosing strata have been uplifted from a horizontal position below sea level and folded into an elongate anticline that extends along the trend of the Surghar Range.

The structure of the coal-bearing strata is shown by a structure-contour map of the Makarwal coal bed (pl. 3). In effect, the structure contours would represent the topography of the coal bed if the overlying rock and coal bed were removed.

The information necessary for the preparation of the structure-contour map came from underground mapping of the coal mines, mapping of coal outcrops, and projection of the structure of overlying formations to the coal seam. The structure map must be regarded as preliminary; refinement and revisions of structure will be possible when more subsurface data become available and a large-scale topographic map is made of the entire coal field area on a single survey network.

\section{FOLDS}

The dominant geologic structure in the Makarwal coal field is the north-trending Makarwal anticline (pl. 3). The anticline is asymmetric; strata on the west limb dip from $30^{\circ}$ to about $40^{\circ}$, and the strata on the east limb are steeply inclined to vertical. Because the anticline plunges southward, the highest coal is in the northern part of the coal field, where it is mined at an altitude of $2,600 \mathrm{ft}$ above sea level. The lowest exposures of coal are in the southern part of Lumshiwal Nala, where it crops out in the anticlinal crest at an altitude of only $1,700 \mathrm{ft}$. The main north-south anticlinal axis is not continuous but is actually composed of a series of en echelon anticlinal segments, each of which trends south-southwest.

\section{FAULTS}

Faults that cut the coal bed in the Makarwal coal field are numerous and create difficulties in mining. Most of the faults have small displacements and are limited in vertical extent; they resulted from local folding of the strata. Other faults having displacements of several hundred feet are the result of regional mountain-making forces that shaped the structure of the Trans-Indus Mountains.

The faults having relatively small displacement are the most important with regard to coal production because they are so numerous. The arching of the strata in the formation of the Makarwal anticline produced fractures that formed the keystone-shaped fault blocks common in the anticlinal area of the coal field. The largest of these in terms of vertical displacement of strata and lateral persistency is called the Zaroba fault (Gee, 1938, p. 286) after the nala that extends along it. Movement of this fault was vertical; the coal on the west side of the fault moved up $500 \mathrm{ft}$ with respect to the coal on the east side (see section $\mathrm{H}-\mathrm{H}^{\prime}, \mathrm{pl}$. 2).

Another fault that greatly affects future development of the coal is at the end of the Central Tunnel where the Makarwal coal bed is in fault contact with the basal beds of the Patala Shale, indicating that the coal on the west side of the fault has dropped down as much as $500 \mathrm{ft}$. A straightforward interpretation of the structure, based on the fault surface observed at the end of the Central Tunnel, is shown in the cross section along the tunnel (fig. 6). However, the location of the surface trace of this fault is not known; if it extends upward on the inclination observed in the Central Tunnel, the fault should appear along the upper face of the cliff or immediately west of the cliff, as shown on the cross section. If the faulting occurred before the deposition of post-Eocene rocks, erosional bevelling before the deposition of the succeeding post-Eocene rocks would explain why the fault is not evident on the surface. Considerable uplift before the deposition of the post-Eocene rocks is known to have occurred, and it is likely that the uplift was accompanied by faulting.

An alternative explanation is that the Central Tunnel fault is a "blind" fault, the east member of a fault set comprising an inverted keystone as shown on cross section $\mathrm{F}-\mathrm{F}^{\prime}$ of plate 2. The mechanics of the development of such a structure can be conceived as a compressional feature that formed on the flank of the Makarwal anticline converse to the tensional features-grabens that formed on the crest of the Makarwal anticline.

The latter interpretation suggests that only a small part of the block west of the tunnel fault is downfaulted and that a short distance beyond the fault block the coal is undisturbed. This interpretation was employed in the construction of the structure contours (pl. 3). Other interpretations are possible, of course, but those mentioned employ much of the structural and stratigraphic information observed in the coal field.

The major fault system of the area is represented by the strike-slip Miranwal fault (pls. 2 and 3) named after Miranwal Nala (pl. 2), where the fault can be observed. The rocks east of the fault moved approximately $4,500 \mathrm{ft}$ southward with respect to the rocks west of the fault. This estimate of displacement is based on the assumption that the block of Chichali Formation, west of the power plant, that originally lay along the east limb of the Makarwal anticline in the vicinity of the Central Tunnel, has been displaced southward along the Miranwal fault.

The Miranwal fault is a single-fault surface in the Miranwal Nala area, but farther south the fault bifurcates and in the Lumshiwal Nala area branches into several faults, some of which are observed on the south side of Lumshiwal Nala. The exposed rocks south of 


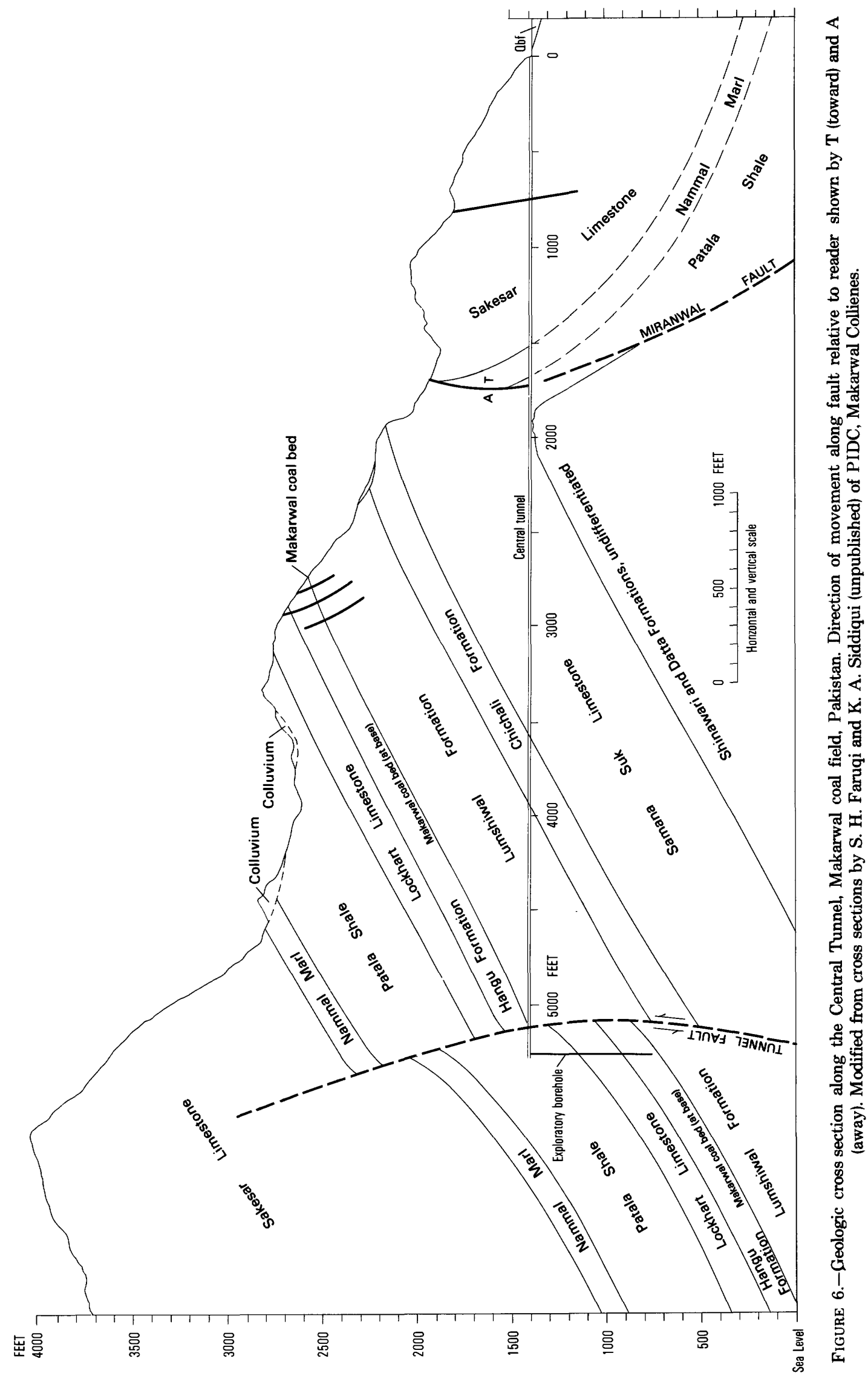


Lumshiwal Nala were not extensively displaced along these faults. Therefore, to account for the large lateral slip along the Miranwal fault zone north of Lumshiwal Nala, flattening into an east-trending branch of the main Miranwal fault where it crosses Lumshiwal Nala is postulated. Along this branch the south-moving rocks are thought to have been swept around the buttress formed by the Sakesar Limestone in the east limb of the Makarwal anticline south of the power plant. The faults observed in the Sakesar Limestone south of Lumshiwal Nala would not be considered primarily part of the Miranwal fault zone, because the faults in the buttress may have developed from the effect of pressure of impinging rocks east of the Miranwal fault.

The coal-bearing rocks on the east side of the Miranwal fault may be immediately below the alluvial fan of the Lumshiwal Nala, where they are probably deformed and shattered; the rocks west of the power plant are thought to have been deformed while being pushed around the buttress of the Sakesar Limestone immediately south-southwest of the power plant. Drilling in Lumshiwal Nala in 1964 disclosed that the buttress of Sakesar Limestone is itself the upper plate of a thrust fault that, according to S. H. Faruqi (Pakistan Industrial Development Corp., written commun.), has overridden the basal formations of the Siwalik Group (fig. 7).

The anticlinal structure beneath the thrust plate in the Lumshiwal Nala cross section is postulated to accommodate the Siwalik rocks identified in core samples from the Lumshiwal Nala exploratory borehole (fig. 7). In the course of geologic mapping of the coal field, a thrust fault - marked $T$ in the southeastern corner of the coal field geologic map (pl. 2) - was observed and assumed to extend into the general area of the borehole. However, a thrust fault of the magnitude shown in the Lumshiwal Nala cross section was neither expected nor indicated from any interpretation of the regional geology of this area (pl. 1). The easternmost outcrop of Sakesar Limestone, shown as a thrust plate of the flattened Miranwal fault (fig. 7), is believed by Landis (U.S. Geological Survey, Denver, Colo., oral commun.) to be a slump block. He also regards the isolated small outcrops of Salsesar Limestone in the southeasternmost corner of the coal field geologic map to be accumulations of colluvium rather than the flat-bottomed fault sheets of Sakesar Limestone depicted in the eastern ends of cross sections $\mathrm{H}-\mathrm{H}^{\prime}$ and $\mathrm{I}^{-\mathrm{I}^{\prime}}$ (pl. 2). Whether these bodies of rock are southerly extensions of the Sakesar outcrops at the Central Tunnel in shallow, flat thrust fault slices or are indeed colluvial masses does not alter the fact that the area is structurally very complicated. The alluvial fans on the mountain front completely conceal all the outcrops that could permit any interpreta- tion of structures in bedrock underlying the alluvial fan and alluvial plain east of the Surghar Range.

\section{GEOLOGIC HISTORY}

The oldest rocks exposed in the area of the coal field (pl. 1) are Jurassic and marine in origin. Strata of the Samana Suk Limestone of Jurassic age and the lowermost beds of the Chichali Formation of Cretaceous age form a continuous record of marine deposition.

Throughout the time that the basal beds of the Chichali Formation were being deposited, much of Pakistan was beneath the surface of the sea. The glauconites of the Chichali Formation are believed to have been formed by alteration of biotite, feldspar, or volcanic rocks in the sea (Pettijohn, 1957, p. 468). A possible source of the parent material of the glauconite may have been widely distributed products of volcanism related to the activity in the Hindubagh district, where boulders of mafic igneous rocks are interbedded with marine rocks of Early Cretaceous age.

During deposition of the marine sedimentary rocks that underlie the Makarwal area, parts of the Salt Range and eastern Trans-Indus Mountains emerged from beneath the sea. In the Salt Range, erosion of the formations older than Cretaceous continued through most of Cretaceous time. However, in the Makarwal area, uplift apparently started later, and the uplifted area was never very high. The glauconitic sandstone in the lower part of the Chichali Formation of the eastern Trans-Indus Mountains was reworked and incorporated into sediments that now comprise the strata of the uppermost part of the Chichali Formation of the Makarwal area. Apparently erosion was less extensive in the Makarwal area; through much of Cretaceous time that area was the site of slow accumulation of sediments that now comprise transition beds between the Chichali Formation and the Lumshiwal Formation.

After erosion had reduced the uplifted areas now occupied by the western Salt Range and eastern TransIndus Mountains to a plain, that area remained stable for most of the remainder of the Cretaceous. At least one climatic episode was favorable for the development of laterite during this time, and lateritic or bauxitic rocks extended over much of the northern part of Pakistan.

In Late Cretaceous or early Paleocene time, fairly rapid subsidence and deposition of sandstone took place throughout the western Trans-Indus Mountains, probably under terrestrial conditions but at an altitude close to sea level. Sedimentation kept pace with subsidence, and coaly shale and coal were deposited in the Makarwal area. During the time the Makarwal coal was being deposited, conditions again favored the development of 


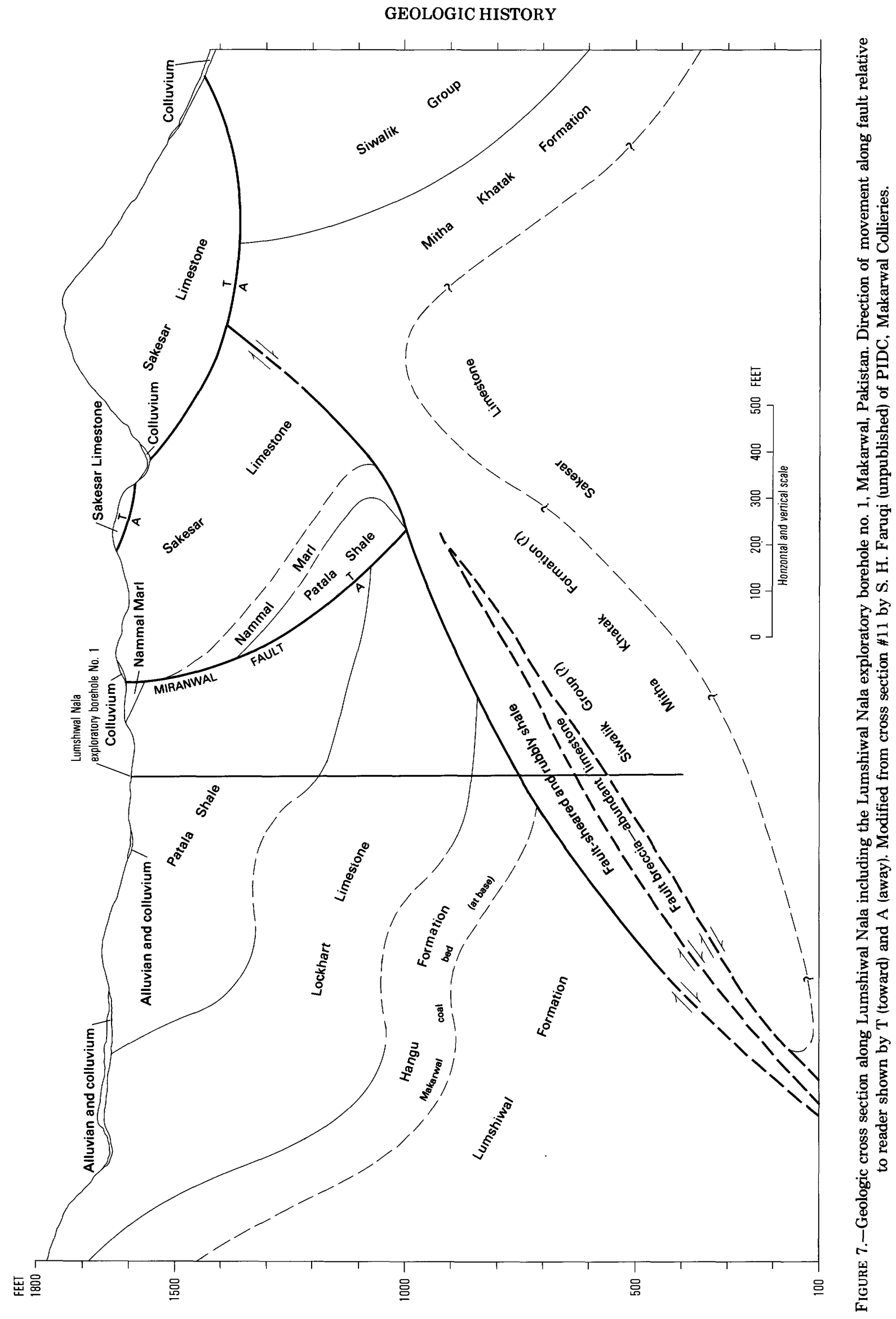


laterites. After the Makarwal coal was laid down, sand was deposited over much of the Salt Range area.

During Paleocene and early Eocene time most of Pakistan was submerged and received thick deposits of marine limestone and clay.

During Eocene or perhaps Oligocene time, strong mountain-building forces folded the rocks into broad northwest-trending folds that formed islands in a shallow marine seaway. Some islands were bevelled by erosion and covered by sediments, while others continued to rise and formed mountains similar to those of today. Possibly the Tunnel fault was produced during this uplift. Erosion of these strongly uplifted rocks provided the cobbles and pebbles of the lower part of the Mitha Khatak Formation.

After the seaways in which rocks of the Mitha Khatak Formation were deposited became filled, the sea retreated southward and the Makarwal area became a broad, perhaps transitionally grassy plain. In late Pliocene time the area became part of a large depositional basin of rapid terrestrial sedimentation. These terrestrial rocks comprise the Siwalik Group, which crops out extensively in the Salt and Surghar Ranges.

During deposition of the thick sandstone, shale, and siltstone beds of the Siwalik Group, the Makarwal region subsided rapidly without interruption. The depositional history of the Siwalik Group ended with the resumption of mountain-building activity that started tens of thousands of years ago and continues today. The earliest phase in this tectonic episode was the folding that produced the north-trending Makarwal anticline, the major structure of the western Surghar and Shinghar Ranges. The folding was accompanied by normal faults that formed along the flanks of the Makarwal anticline and, perhaps, the thrust fault found in the Lumshiwal Nala exploratory borehole (fig. 7).

A second phase of tectonic activity involving the Makarwal coal formed the east-trending central part of the Surghar and Shinghar Ranges. The compressive forces that produced the structures in this area also produced the Miranwal strike-slip fault.

After uplift of the area, incisement and headward erosion of streams produced the steep cliffs and rugged topography of the Surghar and Shinghar Ranges. These processes continue today; material eroded from these mountains is being deposited on the adjacent Bannu and Indus Plains (fig. 2). Generally, the plains appear to be subsiding at nearly the same rate as the alluvial material is being deposited, although some places have been uplifted. Near Kalabagh (fig. 2), for example, Holocene gravel and alluvial deposits derived from the mountains to the west have been raised several hundred feet above the present level of the Indus River. Also, immediately northwest of the Makarwal railroad station, outcrops of strongly cemented alluvium (pl. 1) that protrude above unconsolidated modern alluvium may represent recently uplifted areas.

\section{ECONOMIC GEOLOGY}

\section{COAL RESOURCES}

Nearly all the coal in the Makarwal coal field is produced from the Makarwal coal bed, at or near the base of the Hangu Formation.

\section{THICKNESS OF THE COAL BED}

The Makarwal coal bed ranges in thickness from less than a foot to more than $10 \mathrm{ft}$ (fig. 8). In eight mines the average thickness ranges from 21 to $80 \mathrm{in}$. (table 2); the median value of 246 observed thicknesses at evenly distributed points is 44 in. Commonly, the coal thickens behind the outcrop. Inside the mines, the coal bed pinches and swells in a random way within short distances and without any noticeable trend.

At most places thinning or absence of the coal is due to depositional rather than tectonic causes. Many of the areas where coal is missing are along the anticlinal parts of the coal field, which gives the impression that deformation caused the change in thickness. This is not likely because the forces producing deformation in the axial area are tensional, not compressional. Locally, the coal has an abnormal thickness or is missing because of faulting. This has been observed in the Fakhr-i-Pakistan mine and in the outcrop near the Partap mine. However, the thickening or thinning caused by faults is confined to the fault zone, whereas the primary thinning of the coal bed is gradual and generally widespread, extending over tens of acres.

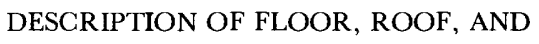

The floor of the Makarwal coal bed is commonly carbonaceous claystone less than $1 \mathrm{ft}$ thick underlain by sandy lateritic gray claystone that weathers bright red. The lateritic claystone, which is as much as $9 \mathrm{ft}$ thick locally, is present throughout the southern part of the coal field but absent in the northern part. The roof of the Makarwal coal bed differs in lithology from place to place; most commonly it is durable carbonaceous claystone less than $1 \mathrm{ft}$ thick, overlain by fine- to mediumgrained sandstone that forms the roof rock where the claystone is absent.

Partings in the coal bed, present in many parts of the coal field, are most commonly carbonaceous claystone less than 6 in. thick and apparently local in distribution. Thick, persistent partings are present in the Fakhr-iPakistan mine and in the basal part of the coal near the 


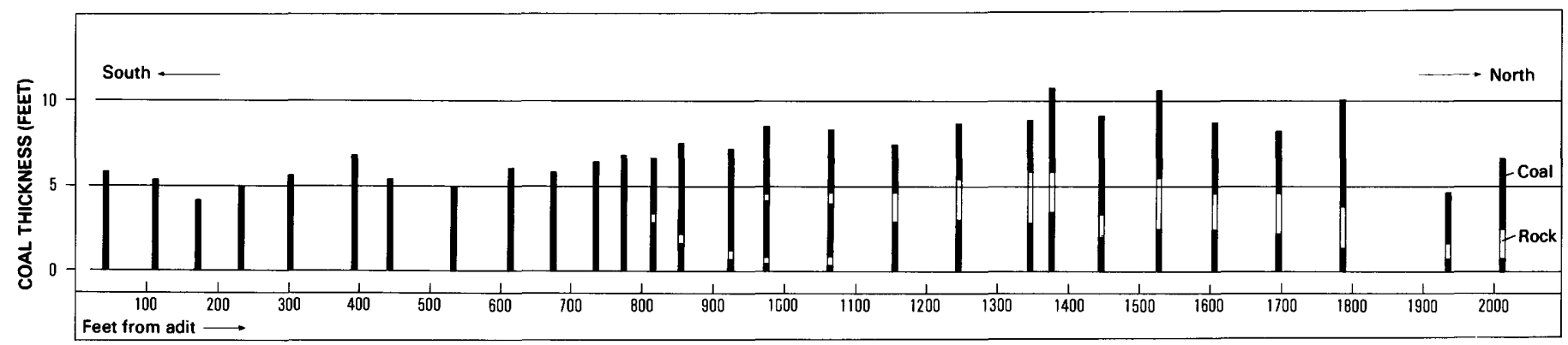

FIGURE 8.-Coal thickness diagram, main haulage slope, Faqr-i-Pakistan mine, Makarwal, Pakistan. Thicknesses measured by N. A. Bhatti, Geological Survey of Pakistan.

TABLE 2.-Summary of coal thickness measurements [Thicknesses measured by N. A. Bhatti, geologist, Geological Survey of Pakistan, 1961]

\begin{tabular}{lcccc}
\hline & \multirow{2}{*}{$\begin{array}{c}\text { No. of } \\
\text { observations }\end{array}$} & \multicolumn{3}{c}{ Thickness (in.) } \\
\cline { 3 - 5 } & & Range & Median & Average \\
\hline Lamshiwal-Asar (Dilbagh) -- & 19 & $40-56$ & 47 & 47 \\
Fakhr-i-Pakistan ---------- & 69 & $46-128$ & 78 & 80 \\
New Miranwal ----------- & 15 & $24-78$ & 34 & 44 \\
Ganjina-i-Pakistan 2------- & 19 & $21-59$ & 27 & 31 \\
Ganjina-i-Pakistan 3------ & 46 & $42-84$ & 54 & 53 \\
Ram Saran ------------- & 14 & $17-67$ & 45 & 43 \\
Zora --------------- & 26 & $12-37$ & 20 & 21 \\
New Tunnel ----------- & 38 & $10-57$ & 25 & 27 \\
\hline
\end{tabular}

Central Tunnel. These thick partings consist of carbonaceous claystone that grades laterally into very fine grained carbonaceous sandstone.

\section{QUALITY}

The analyses of Makarwal coal (table 3) show that the fixed carbon of moisture- and ash-free coal is in the range 46 to 51 percent. Coal with this range of carbon content is ranked according to its calorific value on a moist, mineral-matter-free basis, and on whether the coal is agglomerating or nonagglomerating. A true rank classification requires that sampling of the coal comply with procedures set in the American Society for Testing Materials specifications (ASTM, 1967, D388-66, sec. 5).

Complete sampling informaton for the coal from Makarwal is not available. Moreover, according to R. F. Abernethy (U.S. Bureau of Mines, Pittsburgh, written commun., March 6,1970), the analyses of these samples indicate that some moisture of the coal had been lost in sampling or transit, so the calorific determination on a moist, mineral-matter-free basis is questionable. Thus a true rank classification of these coal sample analyses cannot be made. However, Mr. Abernethy writes that he has

*** estimated the rank of the coals in this series [of samples] from other characteristics. Some of the samples showed slight caking tendencies by the agglomerating index test, and was confirmed by the free-swelling, and the agglutinating indexes. Other samples showed noncaking characteristics. The agglomerating index (ASTM, $1967, \mathrm{D} 388-66$, sec. 8 ) is used to differentiate between high-volatile C bituminous and subbituminous A groups and is not subject to substantive variations in moisture content.

Mr. Abernethy concludes that in his opinion "these coals would have been classified in the 'high-volatile $\mathrm{C}$ bituminous' and 'subbituminous A' groups if [currently] valid analyses had been used." This classification is here adopted as the apparent ranks of Makarwal coal.

The coal is remarkably low in degree of coalification when it is considered that the coal has been overlain by rock $3 \mathrm{mi}$ thick and was involved in two episodes of intense mountain-making deformation that uplifted the strata from horizontal to nearly vertical.

The analysis of the first sample in table 4 , described as "run of mine," is a representative analysis of coal being produced in the coal field on August 4, 1952. The sample was collected at Mari Indus from deliveries totalling 126 tons that were used for a screening test. The proximate analysis of this sample compares closely to earlier published analyses reproduced in table 4 from Gee (1938, p. 283).

The "Lumshiwal group of mines" in table 4 is probably comparable to the channel samples from the Fakhri-Pakistan mine described in the "as received" proximate analyses in table 3 . This comparison confirms that coal from the southern part of the coal field generally has more ash than coal from the northern part.

The sulfur content, which ranges from 4.1 to 5.6 percent, shows little relationship to ash content. From this it can be inferred that much of the sulfur is organic and pyritic sulfur disseminated within the coal. 
STRATIGRAPHY AND COAL RESOURCES, MAKARWAL AREA, PAKISTAN

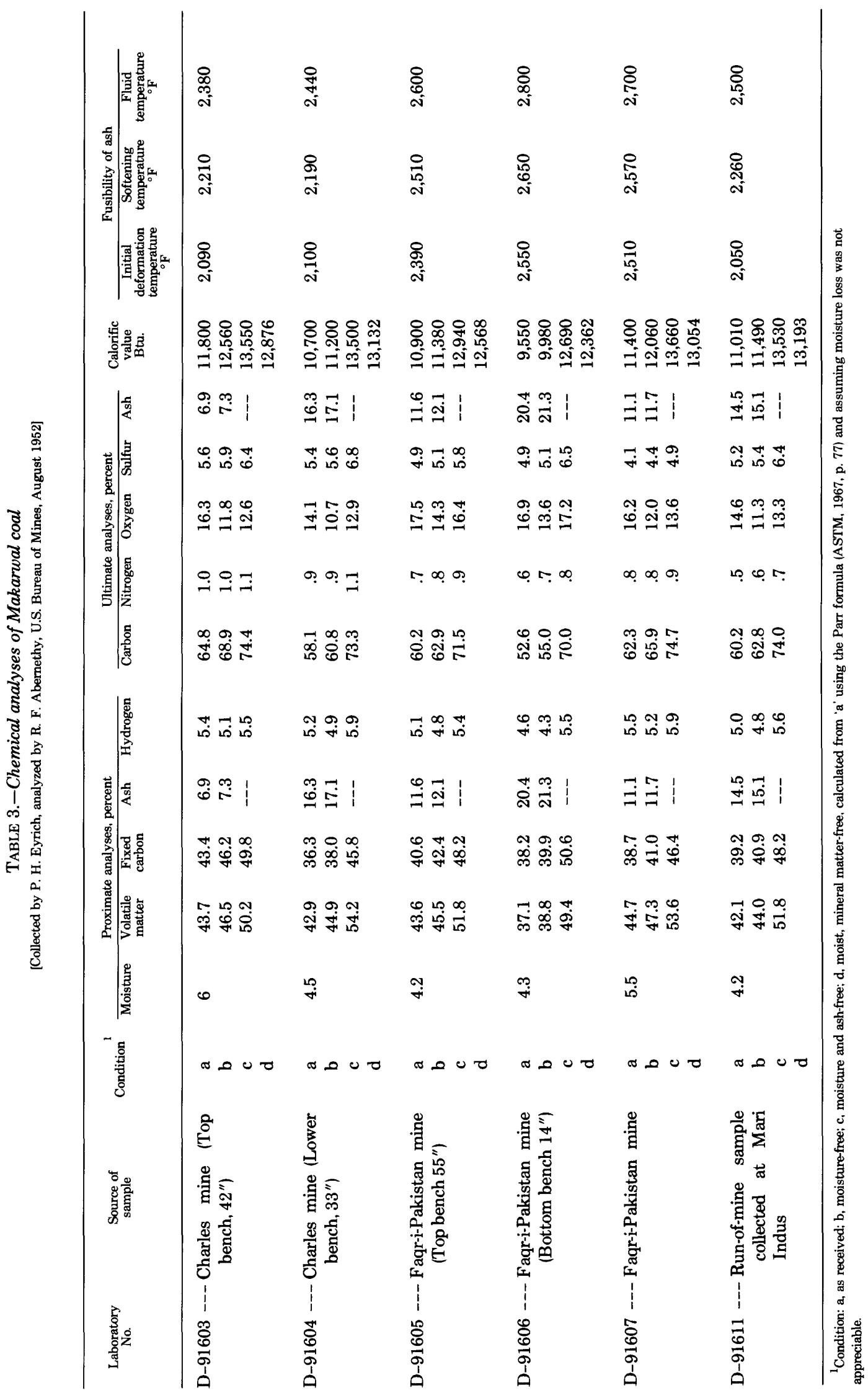


TABLE 4.-Comparison of proximate analyses of Makarwal coal

\begin{tabular}{lccc}
\hline & $\begin{array}{c}\text { Run-of-mine } \\
\text { Mari Indux, 1952 } \\
\text { (from table 3) }\end{array}$ & $\begin{array}{c}\text { Run-of-mine } \\
\text { Makarwal, 1936 } \\
\text { (Lumshiwal group } \\
\text { of mines) }\end{array}$ & $\begin{array}{c}\text { Run-of-mine } \\
\text { Makarwal, 1936 } \\
\text { (Simpson group } \\
\text { of mines) }\end{array}$ \\
\hline Moisture -- & 4.2 & 2.8 & 3.04 \\
Volatile matter ---- & 42.1 & 42.34 & 43.43 \\
Fixed carbon - & 39.2 & 38.94 & 44.29 \\
Ash -- & 14.5 & 17.92 & 9.24 \\
\hline${ }^{1}$ From Gee (1938, p. 283). & & &
\end{tabular}

The coal is locally regarded as lignite because the powdered coal is brown. The coal is soft, but bright, and it breaks down easily into fine pieces or powder, because cleats are closely spaced.

Table 5 shows the size distribution of coal for the sample of "run of mine" coal discussed above.

\section{PRODUCTION}

Coal was mined as early as 1903 (Ball and Simpson, 1913 , p. 111) but no production records were published until 1914.

The total coal produced in the Makarwal coal field from 1914 to 1976 is estimated to be $4,900,000$ tons. The production figures listed in table 6 include published data for 1914 to 1937 taken from Gee (1938, p. 292). These figures do not include the Chashmia mine area, which had not yet been developed. No information is available for the 9-year period, 1936 through 1944, inclusive. The production estimate of 720,000 tons for this period is based on the arbitrarily assigned amount of 80,000 tons per year. Production figures for the interval 1945 to 1976 were provided by the PIDC.

Annual production after 1957 rose to more than 100,000 tons in response to revitalization of the mines by the operators, PIDC. The sharp increase in production after 1963 reflects the completion and use of the Central Tunnel haulage way which permitted tapping new reserves above the haulage way.

Production through 1962 was 2.7 million tons. Assuming a 60 percent rate for recovery, the mined coal represents a depletion of 4.5 million tons of coal. This very nearly corresponds to the original reserves, that is, of coal that was originally present in the areas that had been developed by 1962. Much of the coal that remained in the developed areas after 1962 has already been extracted, its recovery having been enhanced by the availability of the Central Tunnel haulage way.

The value of 1,581 long tons per acre-ft (Averitt, 1969, p. 21) was used, assuming that the specific gravity of

\begin{tabular}{|c|c|}
\hline \multicolumn{2}{|l|}{ [Screens set at $30^{\circ}$ to the horizontal. Data from P. R. Eyrich, U.S. Bureau of Mines] } \\
\hline & Percent \\
\hline \multicolumn{2}{|l|}{ Coal passing through } \\
\hline 1/4-inch square mesh - & 41.1 \\
\hline 1/2-inch round on $1 / 4$-inch square mesh -- & 15.8 \\
\hline 1-inch square mesh on 1/2-inch round -- & 18.7 \\
\hline 1 1/2-inch round on 1-inch square mesh -- & 8.7 \\
\hline Retained on $11 / 2$-inch roun & 15.7 \\
\hline
\end{tabular}

the coal is approximately 1.3. The size of the subdivided areas, thicknesses, and calculated reserves are given in plate 4 . The factors taken into account are sufficient to bring the computations to represent the actual tonnage of coal, with a possible error of 20 percent. The ash content of the coal in the area has a range (table 4) sufficient to make the specific gravity differ by one-tenth, a difference of 7 percent by weight.

\section{RESERVES}

Method of calculating reserves.-The coal-bearing areas shown on figure 6 were divided into subareas (pl. 4), one where coal had been developed and another between the 1,400-foot contour (above sea level) and the areas where coal has been developed. These were further subdivided into areas to which different thicknesses were assigned. A polar planimeter was used to measure the areas; a factor to account for dip was applied to the measurements. Assigned thicknesses were derived from medians of measured thicknesses. The medians were preferred to the arithmetic means in order to eliminate the effect of very high or very low thicknesses recorded in some subareas. In most subareas, however, the average values were found to correspond closely to the median.

Classes of reserves.-Measured, indicated, and inferred reserves are the three categories used in this report to classify coal reserves. The classification is based on the relative reliability of thickness information.

Measured (remaining) reserves: Measured reserves were computed for areas reported to have been mined and the areas between mines to the depth of the workings. A median thickness was used where thicknesses were measured, but, for the mined-out areas where thickness could not be measured, the value of $3 \mathrm{ft}$ and $4 \mathrm{ft}$ were used because they are the most probable thickness for those areas. 
TABLE 6.-Coal production, Makarwal coal field, 1914 to September 1968

[In long tons of $2,240 \mathrm{lb} / \mathrm{ton}$ ]

\begin{tabular}{|c|c|c|c|c|c|c|c|}
\hline Year & $\begin{array}{l}\text { Production } \\
\text { in tons }\end{array}$ & Year & $\begin{array}{l}\text { Production } \\
\text { in tons }\end{array}$ & Year & $\begin{array}{l}\text { Production } \\
\text { in tons }\end{array}$ & Year & $\begin{array}{l}\text { Production } \\
\text { in tons }\end{array}$ \\
\hline 1914 --------- & 1,557 & $1930-\cdots$ & 20,011 & 1953 & 41,252 & $1969-----$ & 205,968 \\
\hline 1915 & 2,029 & $1931---$ & 22,831 & 1954 & 42,185 & 1970 & 198,754 \\
\hline 1916 & 817 & $1932-\cdots--$ & 30,792 & $1955 \ldots$ & 50,898 & $1971 \ldots$ & 188,375 \\
\hline 1917 -------- & 2,916 & 1933 & 45,581 & 1956 --_----- & 58,458 & 1972 & 200,048 \\
\hline 1918 - - & 5,151 & 1934 & 64,986 & $1957-\ldots$ & 96,623 & $1973----$ & 170,018 \\
\hline $1919-\cdots$ & 5,822 & $1935-------$ & 77,073 & $1958 \ldots$ & 136,169 & 1974 & 160,731 \\
\hline $1920----$ & 6,835 & 1936 to & & $1959-\cdots--$ & 105,282 & 1975 & 142,195 \\
\hline 1921 - - & 11,853 & 1944 incl. & $720,000^{1}$ & 1960 & 111,038 & 1976 & 111,080 \\
\hline 1922 - & 14,301 & $1945----$ & 83,219 & $1961-$ & 117,203 & \multirow[t]{8}{*}{ Total - - - - } & \multirow[t]{8}{*}{$4,985,262$} \\
\hline 1923 & 11,965 & 1946 & 84,196 & $1962--\cdots---$ & 127,771 & & \\
\hline $1924-\ldots-$ & 18,787 & 1947 - & 66,637 & $1963 \ldots$ & 135,406 & & \\
\hline $1925-\cdots--$ & 18,341 & 1948 - ------ & 97,482 & $1964-\cdots$ & 134,827 & & \\
\hline 1926 & 15,644 & 1949 & 91,515 & $1965-\ldots$ & 132,035 & & \\
\hline 1927 --_-_--- & 15,488 & $1950 \ldots$ & 77,829 & 1966 & 136,302 & & \\
\hline 1928 - & 18,161 & $1951-------$ & 77,604 & $1967--$ & 159,117 & & \\
\hline 1929 & 19,064 & $1952------$ & 60,752 & 1968 - ----- & 151,586 & & \\
\hline
\end{tabular}

${ }^{1}$ Estimated.

Indicated reserves: The coal in the areas that lie below the mine workings to a depth of $1,000 \mathrm{ft}$ above sea level comprises the indicated reserve. The thickness data were extended to the depth of $1,000 \mathrm{ft}$ above sea level from the areas where measurements were made.

Inferred reserves: The inferred reserve is calculated on the inference that the coal, from the altitude of $1,000 \mathrm{ft}$ above sea level to $200 \mathrm{ft}$ below sea level, will have the same thickness as the coal above $1,000 \mathrm{ft}$. The estimate is confined to the west limb and the crestal area of the Makarwal anticline, because the attitude of the rocks is probably the same to at least $200 \mathrm{ft}$ below sea level. Much of the area underlain by coal in this category extends beyond the west edge of the area shown in plate 4.

Reserves of coal.-The total reserve of coal in the Makarwal coal field, estimated to a depth of $200 \mathrm{ft}$ below sea level, is $16,600,000$ tons. The reserves, according to classes, are given in table 7 . The areal distribution of measured and indicated coal reserves, and coal thicknesses are shown in plate 4 . The coal measured in the developed areas and old workings is now probably totally depleted or is unrecoverable in pillars and barriers.

Comparison with other reserve estimates.-References to Makarwal coal reserves include a published report by Khan (1949) and two reports written for the Pakistan Government by the consulting firm Powell Duffryn (the latest issued in 1959).

Khan's $(1949$, p. 7 ) estimate of total reserves was 9.7 million tons and included (1) proven reserves "available from the present mine workings," and (2) probable reserves "that may be available from the western limb of the anticline and other undeveloped tracts $* * *$ along the dip for one-fourth mile." (p. 3). Khan's "probable reserve" corresponds to the "indicated reserve" as used in this report, although his parameters for calculation are different from those used in this investigation.

\section{OTHER MINERAL RESOURCES}

The Makarwal coal field contains large amounts of stone used locally for mine, road, and dwelling construction. Sakesar Limestone can be trimmed and dressed easily and is commonly used for dimension stone. Lockhart Limestone is commonly used for packing in the coal mines because it is conveniently located above the adits and its nodules are of a suitable size and shape for the purpose.

Economic deposits of clay are not available in the mapped area. The underclay of the Makarwal coal bed is iron-rich and contains medium- to coarse-grained quartz; therefore, it probably cannot be used in highquality ceramic ware. The Patala Shale is rich in calcareous matter and cannot be used for most ceramic purposes. Clay from which bricks are manufactured on a small scale is available in the plains east of the mapped area.

A vast reserve of dolomite of the Kingriali Dolomite is present immediately north of the coal field, but is not being exploited. The formation is more than $300 \mathrm{ft}$ thick, and the outcrop extends more than $7 \mathrm{mi}$ along the foot of the Surghar escarpment. A chemical analysis of a 6-foot channel sample collected in Khatkiara Nala $1 \mathrm{mi}$ 
TABLE 7.-Coal reserves of the Makarwal coal field

\begin{tabular}{lc}
\hline \multicolumn{1}{c}{ Class } & Reserve, in long tons \\
\hline Original - & $4,474,000$ \\
Less production to Dec. 1976 - & $4,902,560$ \\
Remaining (after 1976) reserve - & 0 \\
$\begin{array}{l}\text { Indicated reserve (from the mine workings to a } \\
\text { depth of } 1,000 \text { ft above sea level) --- }\end{array}$ & $7,381,000$ \\
$\begin{array}{l}\text { Inferred reserve (from } 1,000 \mathrm{ft} \text { above sea level to } \\
200 \mathrm{ft} \text { below sea level) --- } \\
\text { Total }\end{array}$ & $9,184,000$ \\
\hline
\end{tabular}

north of Malla Khel was analyzed by E. H. Chauhan; results are as follows:

$\begin{array}{lr} & \text { Percent } \\ \mathrm{CACO}_{3} & 53.50 \\ \mathrm{MgCO}_{3} & 44.55 \\ \text { Manganese } & \text { Trace } \\ \text { Insoluble residue } & .28\end{array}$

Greensand, glass sand, and limestone are the mineral resources within the coal field that may be of immediate economic significance. A sedimentary iron-formation accessible via coal-mining facilities comprises a large potential resource of iron.

\section{GREENSAND}

The upper part of the Chichali Formation in the Makarwal area contains glauconite-rich sandstone called "greensand," which consists mostly of glauconite grains in the matrix of calcium carbonate and iron carbonate. Possible uses for the greensand include direct application as a soil conditioner, fertilizer, a source of potassium and iron, and a water-softening agent.

Greensand has been used in the United States and elsewhere as a source of potassium; when applied to the soil, it provides a slow but steady source of potassium available for growing plants. Table 8 compares chemical composition of greensand from the United States used for agriculture purposes and samples of greensand from Baroch Nala. Results of tests on use of greensand were described by Bakhsh and others (1963); they report that the potash content of the greensand is too low to consider its use as a fertilizer. However, they found that the greensand is effective as a water softener.
TABLE 8.-Chemical analyses (ranges, in percent) of greensand from the United States and from Baroch Nala in the Makarwal coal field

\begin{tabular}{|c|c|c|}
\hline & U.S. samples ${ }^{1}$ & Baroch Nala ${ }^{2}$ \\
\hline $\mathrm{SiO}_{2}$ & 40.0 to 60.1 & 22.2 to 29.8 \\
\hline $\mathrm{Fe}_{2} \mathrm{O}_{3}-\mathrm{FeO}$ & 18.9 to 21.1 & 40.1 to 50.4 \\
\hline $\mathrm{MgO}$ & 1.7 to 4.1 & Not determined \\
\hline $\mathrm{CaO}-\mathrm{C}_{-1}$ & 1.2 to 10.4 & 0 to 3.0 \\
\hline $\mathrm{Na}_{2} \mathrm{O}$ & 0.5 to 4.8 & 0.10 to 0.12 \\
\hline n-n & 2.1 to 7.6 & 2.5 to 4.3 \\
\hline $\mathrm{P}_{2} \mathrm{O}_{5}$ & 0 to 0.95 & 0.45 to 0.7 \\
\hline
\end{tabular}

${ }^{1}$ Kelly, 1923, p. 223 .

${ }^{2}$ From analyses by E. J. Fennelly, W. Mountjoy, H. H. Lipp, and D. L. Skinner, U.S. Geological Survey (see table 9).

IRON

Iron-rich rock is present within a sequence of greensand layers in the upper part of the Chichali Formation and is the object of continuing detailed investigations as a possible ore of iron by the Pakistan Industrial Development Corporation. This stratum, the ironformation of the Chichali gorge area, has been investigated by the Geological Survey of Pakistan.

J. J. Matzko and Mahnoon Hasan (written commun., 1967) investigated the mineralogy and genesis of the iron-rich beds of the Makarwal and Chichali areas. They identified the iron-rich minerals at Makarwal as goethite (41.7 to 81.5 percent) altered from glauconite, and glauconite (1.7 to 22.6 percent) in a carbonate (dolomite?) cement and matrix (7.1 to 53 percent). Samples of the iron-rich beds from the Chichali area have a mineral composition that also includes goethite (21.8 to 88.1 percent) and glauconite (7.9 to 41.3 percent), with carbonate minerals (dolomite and ankerite) ranging from 3.3 to 38.1 percent.

The iron-rich beds extend into the Makarwal area, where the stratum of iron-rich rock is only $2.5 \mathrm{ft}$ thick. However, at Makarwal a second stratum of iron-rich rock is present $53 \mathrm{ft}$ below the layer described by Aftab Ali (geologist, PIDC, in Matzko and Hasan, 1967, p. 10) as the extension of the iron-rich bed at Chichali. This second stratum, referred to as the "Makarwal iron horizon," is as much as $25 \mathrm{ft}$ thick in the Central Tunnel. During this investigation a channel sample was collected immediately above Baroch Nala where the ironrich beds are approximately $20 \mathrm{ft}$ thick. The chemical analyses of the samples are given in table 9 . 
TABLE 9.-Chemical analyses (in percent) of a channel sample of the iron-rich beds, Baroch Nala, Makarwal coal field [Analysts: E. J. Fennelly, W. Mountjoy, H. H. Lipp. D. L. Skinner, and I. C. Frost, U.S. Geological Survey, Denver, Colorado]

\begin{tabular}{|c|c|c|c|c|c|c|c|c|c|}
\hline Thickness & $\begin{array}{l}\text { Total } \\
\begin{array}{c}\text { Tea as } \\
\mathrm{Fe}_{2} \mathrm{O}_{3}\end{array}\end{array}$ & $\mathrm{SiO}_{2}$ & $\mathrm{Al}_{2} \mathrm{O}_{3}$ & $\mathrm{CO}_{2}$ & $\mathrm{CaO}$ & $\mathrm{Na}_{2} \mathrm{O}$ & $\mathrm{P}_{2} \mathrm{O}_{5}$ & $\mathrm{~K}_{2} \mathrm{O}$ & $\begin{array}{l}\text { Loss on } \\
\text { ignition }\end{array}$ \\
\hline \multicolumn{10}{|l|}{ Top of bed } \\
\hline 5.0 feet - & 50.45 & 22.15 & 5.83 & 2.1 & 0.03 & 0.11 & 0.45 & 2.52 & 12.72 \\
\hline 5.0 feet -- & 43.68 & 29.85 & 9.02 & 1.5 & 0.05 & 0.10 & 0.45 & 2.47 & 13.65 \\
\hline 4.9 feet - & 50.36 & 23.90 & 9.14 & 0.6 & 0.18 & 0.10 & 0.45 & 2.53 & 11.64 \\
\hline 4.6 feet - & 44.83 & 25.04 & 8.92 & 2.5 & 3.02 & 0.12 & 0.77 & 3.07 & 12.73 \\
\hline 2.0 feet - & 40.12 & 29.45 & 7.74 & 2.8 & 0.11 & 0.10 & 0.48 & 4.26 & 12.74 \\
\hline Bottom of bed & & & & & & & & & \\
\hline
\end{tabular}

Between the Central Tunnel and Baroch Nala the iron-rich beds have reserves exceeding 45 million tons. At least one outcrop between these two locations verifies the continuity of the iron-rich beds, so that this reserve can be regarded as measured.

\section{GLASS SAND}

The Makarwal coal field contains thick beds of quartz sandstone within the Lumshiwal and the Hangu Formations. No chemical studies of the purity of this sandstone were made in the course of this investigation. However, on the basis of superficial examination, the sandstones are probably not suitable for high-quality glass. Most of the impurity is expected to be in the form of pyrite or marcasite, which is present as fine-grained crystals. Possibly these could be easily separated out of the sandstone by mechanical means at sufficiently low cost to make the sandstone an economic source of glassmaking raw material.

The Lumshiwal Formation in the Central Tunnel is white, friable, and very fine grained. Locally, outcrops of these beds are iron-stained by the decomposition of pyrite, and in some places the sandstone is white, owing to the presence of gypsum flakes that produce a rind on the outcrop.

The sandstone of the Hangu Formation is dark gray and appears to be too impure for use as glass sand. However, most of the color is due to carbonaceous matter in the sandstone rather than dark minerals. The Hangu may be better than Lumshiwal Formation as a source of glass sand.

\section{LIMESTONE}

Limestone as a source of raw material for the manufacture of cement is abundant in the Makarwal area. the most favorable limestones for this purpose are expected to be the Lockhart and the Samana Suk (see stratigraphic section, fig. 5).

The Sakesar Limestone would probably not be suited for cement manufacture because it contains siliceous microfossils and flint nodules in many parts of the stratigraphic section.

\section{GROUNDWATER AND ENGINEERING GEOLOGY PROBLEMS}

\section{MINE WATER}

The most important water-bearing units are the Hangu and the Lumshiwal Formations. The static water table in the mines is approximately $1,622 \mathrm{ft}$ above sea level in the Ganjina-i-Pakistan mine. The coal mine workings above the water table are dry and dusty. Characteristically, sandstone has a high permeability; therefore both the Lumshiwal and Hangu Formations may be considered causes of water problems in coal mine workings below the water table.

The Lockhart Limestone is not expected to be water bearing because its limestone and marl have low permeability; fracture zones were observed to be tight and well cemented. The Chichali Formation, in the subsurface, was found to be well cemented with calcium carbonate and siderite, thus reducing its permeability to an insignificant amount.

\section{WATER SUPPLY}

Water supply has been a serious problem for many years. Coulson (1938, p. 458) reports that the Makarwal Coal Company used an average of $6,000 \mathrm{gal}$ of water per day; the water was shipped by rail from Kalabagh at an annual cost of Rs. 14,000. Piping the water from Baroch 
Nala, which Coulson reports had a daily flow of 21,250 gal, was considered.

The principal source at present is water piped from a well near the Indus River, about 11 mi east of Makarwal station. The supply is adequate for the mining community and power plant, but it is not sufficient for the neighboring villages, which depend on rainfall collected in concrete tanks.

Heretofore, the resources of ground water in the coal field have been generally poor in quality and low in quantity. All the springs, except those at Kurdi and Makarwal Kheji, yield saline or bitter water due to leaching of the bicarbonate and sulphide-bearing rock found most commonly in the Lumshiwal Formation. The springs in Kurdi and Makarwal Kheji yield sweet water because their source is in the thick cover of scree composed of limestone and other rock free from soluble minerals. These rocks retain rain water that accumulates along the floor of the scree deposit. In this area the floor is Patala Shale.

\section{GAS}

Gas has not been reported from any of the old workings, nor from the Central Tunnel that passed through several formations and could contain gas. However, the possibility of finding gas in the new development should not be dismissed.

Gas is known to be present in rocks of Tertiary age in the Trans-Indus Mountains. Flammable gas, called methane, caused fatalities in an explosion at the Kuch iron exploratory tunnel north of Kalabagh. The source of this gas is thought to be the carbonaceous basal beds of the Hangu Formation.

Drilling at Chichali Pass (fig. 2) through the Hangu Formation yielded flammable gas together with artesian water. The gas may be confined to the uppermost beds of the Hangu Formation along the base of the overlying Lockhart Limestone. It is kept from the Makarwal coal bed by the water-saturated sandstone beds immediately above the coal bed, or is sealed off along faults west of the Tunnel fault (fig. 6).

\section{SUMMARY AND CONCLUSIONS}

Makarwal coal is ranked as high-volatile C-bituminous coal containing ash in the range of 6.9 to 21.6 percent. It is in the oldest part of the Tertiary rock section, which is about $3 \mathrm{mi}$ thick in the Makarwal area. The coal is exposed along the flanks of a broad, faulted anticline. Most of the coal is along the western flank of the anticline and dips $30^{\circ}$ uniformly to the west.

The productive life of the Makarwal coal field is estimated to be nearly over if mining is confined to coal above the 1,400-foot level. The coal field, presently being exploited at a rate attaining 500 tons per day, has yielded $4,900,000$ tons of coal since 1914 , at a recovery rate exceeding 80 percent. All the coal developed since the inception of systematic large-scale underground mining in the Makarwal area is rapidly approaching exhaustion.

\section{REFERENCES CITED}

American Commission on Stratigraphic Nomenclature, 1961, Code of stratigraphic nomenclature: Am. Assoc. Petroleum Geologists Bull. v. 45, no. 5, p. 645-665.

American Society for Testing and Materials, 1967, Standard specifications for the classifications of coal by rank (ASTM Designation D388-66), in Gaseous fuels; coal and coke, issued 1967: Am. Soc. Testing Materials, pt. 19, p. 73-78.

Anderson, R. V. I., 1927, Tertiary stratigraphy and orogeny of the northern Punjab: Geol. Soc. America Bull., v. 38, p. 665-720.

Ashley, G. H., and others, 1933, Classification and nomenclature of rock units: Geol. Soc. America Bull., v. 44, pt. 2, p. 423-459.

Averitt, Paul, 1969, Coal resources of the United States, January 1, 1967: U.S. Geol. Survey Bull. 1275, 116 p.

Bakhsh, N., Hussain, M., and Amin, N., 1963, Commercial utilization of greensand as potassic fertilizer and water softener: CENTO Symposium on Industrial Rocks and Minerals, Lahore.

Ball, V., and Simpson, R. R., 1913, The coal fields of India: India Geol. Survey Rec., v. 41, 147 p.

Cotter, G. de P., 1933, The geology of the part of the Attock District west of the Longitude $72^{\circ} 45^{\prime}$ E.: India Geol. Survey Mem., v. 55, pt. 2, 191 p.

Coulson, A. L., 1938, The water supply of the Isa Khel and Mianwali Tehsils of the Mianwali District, Punjab: Geol. Survey India Rec., v. 72, pt. 4, pp. 440-446.

Danilchik, Walter, 1958, Geology of the Developmental Tunnel area, Makarwal Collieries, Mianwali District, West Pakistan: Pakistan Geol. Survey Admin. Report No. 4, 8 p.

1961, The iron formation of the Surghar and western Salt Ranges, Mianwali District, West Pakistan: Art. 371, in U.S. Geol. Survey Prof. Paper 424-D, p. D228-D231.

Davies, L. M., 1930, The fossil fauna of the Samana Range and some adjoining areas: Geol. Survey India Mem., Paleont. Indica, v. 15, $15 \mathrm{p}$.

Davies, L. M., and Pinfold, E. S., 1937, The Eocene beds of the Punjab Salt Range: India Geol. Survey Mem., Paleontologia Indica, new ser., v. 24, no. 1, 79 p.

Eames, F. E., 1952, A contribution to the study of the Eocene in western Pakistan and western India: Part A, the geology of standard sections in the western Punjab and in the Kohat District: Geol. Soc. London Quarterly Journal, v. 107, pt. 2, no. 426, p. $159-171$.

Fatmi, A. N., 1972, Stratigraphy of the Jurassic and Lower Cretaceous rocks and Jurassic ammonites from northern areas of West Pakistan: British Mus. Natural Hist. Bull., v. 20, no. 7, p. $300-381$.

1973, Lithostratigraphic units of the Kohat-Potwar Province, Indus Basin, Pakistan: Mem. Geol. Survey of Pakistan, v. $10,80 \mathrm{p}$.

Fermor, L. L., 1935, General report for 1934: India Geol. Survey Rec., v. 69, pt. 1,108 p.

Gee, E. R., 1938, The economic geology of the northern Punjab, with notes on adjoining portions of the North-West Frontier Province: India Mining Geol. Metall. Inst. Trans. v. 33, pt. 3, p. 263-350. 
1945, The age of the Saline Series of the Punjab and of Kohat: India Nat. Acad. Sciences Proc., Sec. B, v. 14, pt. 6, p. 269-311.

1946, Further note on the age of Saline Series of the Punjab and of Kohat: India Nat. Acad. Sciences Proc. v. 16, pt. (2-4), p. 95-154.

Gill, W. D., 1952, The stratigraphy of the Siwalik Series in the northern Potwar, Punjab, Pakistan: Geol. Soc. London Quart. Jour., v. 107 , pt. 4, no. 428, p. 375-394.

Haque, A. F. M. M., 1956, The smaller foraminifers of the Ranikot and the Laki of the Nammal Gorge, Salt Range: Pakistan Geol. Survey Mem., Paleont. Pakistanica, v. 1, 300 p.

Hemphill, William R., and Kidwai, Abdul H., 1974, Stratigraphy of the Bannu and Dera Ismail Khan quadrangles, Pakistan: U.S. Geol. Survey Prof. Paper 716-B.

Hussain, B. R., 1960, A geological reconnaissance of the Khisor and Marwat Ranges and a part of the Potwar Plateau: unpub. rept. E.S.R./1960. Pakistan Shell Oil Co., Ltd., Karachi; repository, Nat. Stratigraphic Library, Geol. Survey of Pakistan, Quetta.

Kelly, J. W., 1923, Probable cause of the toxicity of the so-called poisonous greensand: Jour. Agricultural Research, v. 23, p. $223-228$.

Khan, N. M., 1949, A survey of coal resources of Pakistan: Pakistan Geol. Survey Rec., v. 2, pt. 2, 11 p., 3 pl.

Krishnan, M. S., 1960, Geology of India and Burma: Higgin brothers (Private) Ltd., Mount Road, Madras, India, 604 p.

Kummel, Berhard, 1966, The lower Triassic formations of the Salt Range and Trans-Indus Ranges, West Pakistan: Mus. Comp. Zoology, Bull., v. 134, no. 10, p. 361-429.

Lewis, G. E., 1937, A new Siwalik correlation: Am. Jour. Science, v. 33, p. 191-204.

Matzko, J. J., and Hassan, Mamnoon, 1975, Mineralogy of ironstones from the Chichali and Makarwal areas, Mianwali and Kohat districts, Pakistan: U.S. Geol. Survey Open-File rept. 75-494 (IR)PK-26, 18 p., 3 tables, 4 figs.

Medlicott, H. B., 1864, On the geological structure and relations of the southern portion of the Himalayan Range between the rivers Ganges and Raves: India Geol. Survey Mem., v. 3, pt. 2, 206 p.

Meissner, Charles R., Master, Jan M., Rashid, M. A., and Hussain, Muzaffar, 1974, Stratigraphy of the Kohat Quadrangle, West Pakistan: U.S. Geol. Survey Prof. Paper 716-D, 30 p., 3 figs., 5 pls.
Morris, T. O., 1938, The Bain Boulder Bed: Geol. Soc. London Quart. Jour., v. 94, pt. 3, p. 385-418.

Oldham, R. D., 1892, Report on the geology of Thal-Chotiali and part of the Mari Country: Indian Geol. Survey Rec., v. 25, pt. 1, p. 1-29.

Pascoe, E. H., 1959, A manual of Geology of India and Burma: v. 2, 3d ed., Govt. of India Press, Calcutta, p. 485-1343.

Pettijohn, F. J., 1957, Sedimentary rocks: 2nd ed., Harper and Bros., New York, $718 \mathrm{p}$.

Pilgrim, G. E., 1913, The correlation of the Siwaliks with mammal horizons of Europe: India Geol. Survey Rec., v. 43, p. 264-326.

Powell Duffryn Technical Services Ltd., 1959, Report on the production and utilizaton of coal in Pakistan: Second Report to the Government of Pakistan, 136 p., 13 pl.

Shah, S. M. I., 1977, Stratigraphy of Pakistan: Mem. Geol. Survey of Pakistan, v. 12, $138 \mathrm{p}$.

Simpson, R. R., 1904, Report on the coal deposits of Isa Khel, Mianwali, Punjab: India Geol. Survey Rec., v. 31, pt. 1, p. 9-34.

Spath, L. F., 1939, The Cephalopoda of the Neocomian Belemnite Beds of the Salt Range: India Geol. Survey Mem., Paleontologia Indica, n.s., v. 25, Mem. no. 1, 154 p.

Stratigraphic Nomenclature Committee on Pakistan, 1962, Stratigraphic code of Pakistan: Pakistan Geol. Survey Mem., v. 4, pt. 1, $8 \mathrm{p}$.

Waagen, William, 1889, Salt Range fossils; geological results: Palaeontologia Indica, ser. 13, v. 4, pt. 1, 88 p.

1891, Salt Range fossils; geological results: Palaeontologia Indica, ser. 13, v. 4, pt. 2, 242 p.

Williams, M. D., 1959, Stratigraphy of the lower Indus Basin, West Pakistan: World Petroleum Congress, 5th, New York, Proc., Sec. 1, paper 19, p. 377-394.

Wynne, A. B., 1877, Note on the Tertiary zone and underlying rocks in the northwest Punjab: India Geol. Survey Rec., v. 10, pt. 3, p. $107-132$.

1878, Geology of the Salt Range in the Punjab: India Geol. Survey Mem., v. 14, 313 p. 1880, On the Trans-Indus extension of the Punjab Salt Range: India Geol. Survey Mem., v. 17, pt. 2, 95 p. 